\title{
B-type Olivine Fabric induced by Grain Boundary Sliding
}

\author{
Jacques Précigout ${ }^{1, *}$ and Greg Hirth ${ }^{2}$
}

\section{Published in Earth and Planetary Science Letters}

${ }^{1}$ Institut des Sciences de la Terre d'Orléans, UMR-CNRS 7327, Université d'Orléans, France

${ }^{2}$ Department of Geological Sciences, Brown University, Providence, RI 02912, USA

*Corresponding author: jacques.precigout@univ-orleans.fr; Tel: +33 (0)2 382553 91;

Fax: $+33(0) 238494476$.

Word count and figures:

- Abstract: 207 words

- Main text: 4247 words

- Figure captions: 1046 words

- Figures: 7

- Supplementary material: 1 table and 1 figure

- Figure captions of supplementary material: 117 words

- References: 51 


\begin{abstract}
Mineral Lattice Preferred Orientation (LPO) in naturally deformed peridotite is typically interpreted to result from the motion of intra-crystalline dislocations during dislocation creep. The degree of mineral alignment (fabric strength) is often assumed to increase with increasing finite strain. Here, we document olivine LPOs in peridotites in a kilometer-scale mantle shear zone in the Ronda massif (Spain) that demonstrate a transition from a flow-parallel [100]-axis LPO (A-type fabric) to a flow-normal [100]-axis LPO (B-type fabric). We conclude that the B-type fabric in the Ronda peridotite results from the enhancement of grain boundary sliding (GBS) with decreasing grain size, rather than a change in the dominant dislocation slip system because: (1) dislocation sub-structures remain consistent with the A-type slip system in all samples; (2) the fabric transition correlates with decreasing fabric strength despite increasing finite strain; (3) the analysis of deformation conditions in Ronda is inconsistent with the experimental conditions, including water content, inferred to promote the dominance of (010)[001] slip in laboratory samples, and (4) our observations are supported by experiments that document B-type fabric in olivine aggregates where deformation involves a component of GBS. Our results have important implications for interpreting the rheological properties of shear zones and upper mantle structures via microstructural and seismic observations.
\end{abstract}

\title{
Running title
}

Olivine fabric induced by GBS

\section{Keywords}

Lattice Preferred Orientation; fabric strength; deformation mechanism; Ronda peridotite 


\section{Introduction}

Strain-induced olivine LPOs have a strong and predictable effect on seismic wave propagation, providing a powerful tool to interpret the kinematics and dynamics of flow within inaccessible regions of the mantle (e.g., Ismaïl and Mainprice, 1998; Silver et al., 1999). However, over the last 10 years or so, numerous experimental results and natural observations indicate that olivine LPO can vary significantly depending on the conditions of deformation. Of particular importance is the observation of B-type fabric, where the olivine [100] axes align in the flow plane, normal to the flow direction and [001] axes align parallel to the flow direction. This fabric geometry strongly affects the relationships between deformation kinematics and seismic anisotropy (e.g., Jung and Karato, 2001). Although critical for the interpretation of upper mantle structure and dynamics, the deformation conditions where olivine B-type fabric develops are still actively debated (e.g., Karato et al., 2008; Sundberg and Cooper, 2008; Kohlstedt and Holtzman, 2009; Jung et al., 2009; Ohuchi et al., 2011).

During viscous deformation, olivine aggregates deform by either motion of intracrystalline defects along lattice-controlled slip systems (dislocation creep), or grain boundary sliding (GBS) accommodated by grain boundary diffusion (diffusion creep) or motion of dislocations (DisGBS). Traditionally, the development of LPO is attributed to viscous deformation by dislocation creep (e.g., Nicolas and Christensen, 1987). In contrast, the weakening or absence of LPO in fine-grained mylonitic rocks is attributed to a transition to diffusion creep (e.g., Fliervoet et al., 1999; Warren and Hirth, 2006; Drury et al., 2011). However, recent experimental observations demonstrate the formation of LPO during diffusion creep of Fe-free olivine (i.e. forsterite) (Miyazaki et al., 2013). Furthermore, olivine B-type fabric has been observed in experimentally deformed harzburgite at conditions where diffusion creep is interpreted to be the dominant deformation mechanism (e.g., Sundberg and 
Cooper, 2008).

In the core of mantle shear zones, substantial grain size reduction may result in a transition from dislocation creep to grain-size-sensitive diffusion creep or DisGBS (e.g., Warren and Hirth, 2006; Drury et al., 2011; Hansen et al., 2011), promoting a decrease in effective viscosity and subsequent strain localization (e.g., Précigout and Gueydan, 2009). Such a mantle shear zone has been documented in the Ronda massif (southern Spain; Van der Wal and Vissers, 1993; 1996; Platt et al., 2003), where strain localization has been interpreted to result from activation of DisGBS (Précigout et al., 2007). In this paper, we investigate the relationships between olivine LPO and deformation mechanisms in the kilometer-scale Ronda shear zone. We illustrate a transition from a flow-parallel [100]-axis olivine LPO (A-type fabric) to a flow-normal [100]-axis LPO (B-type fabric). We then discuss the processes that can induce this transition to B-type fabric in Ronda based on comparison of our results with experimental data and independent constraints on the natural deformation conditions.

\section{The Ronda peridotite}

The Ronda massif belongs to the Betic cordillera in southern Spain and encompasses several sheets of mantle peridotite that were emplaced onto the thinned crust of the internal Betics during the Early Miocene (Fig.1; Van der Wal and Vissers, 1993). During exhumation, the Ronda peridotite experienced several stages of deformation and partial melting, evidence for which is well preserved in the western Ronda massif (Van der Wal and Vissers, 1996). In the northwestern rim of the exposed mantle section, a mylonitic domain overprints a tectonite, which together represent a kilometer-scale mantle shear zone that results from strain localization beneath the host crustal rocks (Fig.1; Van der Wal and Vissers, 1996; Platt et al., 2003; Précigout et al., 2007; 2013); the mylonite and tectonite are classified as subcontinental lithospheric mantle (Van der Wal and Vissers, 1996). The tectonic setting of this 
mantle shear zone is still debated, but the large syn-tectonic decompression recorded in both the mylonite and overlying rocks suggests that deformation occurred during extension of continental lithosphere (Platt et al., 2003; Précigout et al., 2007; Garrido et al., 2011; Précigout et al., 2013).

In the study area, the mylonite and tectonite are mainly composed of serpentinized spinel-bearing lherzolite and harzburgite with minor garnet-bearing peridotite in the uppermost sub-crustal mylonite (Fig.2). These peridotites exhibit a steeply dipping foliation that becomes more pronounced towards the upper mylonite owing to increasing strain. We refer to the lower half of the mylonitic domain, which lies above the tectonite, as the lower mylonite and the upper half of the mylonitic layer, which lies just beneath the host crustal rocks, as the upper mylonite. The stretching lineation, defined by $\mathrm{cm}$-scale elongated orthopyroxene (Fig.2), is close to horizontal and shear criteria indicate sinistral kinematics with a minor component of coaxial shortening (Van der Wal and Vissers, 1996; Balanyá et al., 1997; Précigout et al., 2013).

As shown in Précigout et al. (2013), the large-scale strain gradient across the mantle shear zone has been revealed by the deformation pattern of garnet-bearing pyroxenite layers in both the tectonite and mylonite. In the tectonite, pyroxenite layers show isoclinal folds and modest boudinage. In comparison, they become strongly transposed and highly boudinaged in the lower mylonite, and then highly stretched in the upper mylonite. These structures indicate progressive strain increasing from the tectonite to mylonite as pyroxenite layers rotate with respect to the principal strain axes, leading to a change in their deformation pattern from predominately shortening to stretching (Ramsay, 1980).

Petrological data indicate syn-kinematic temperatures from around $1100^{\circ} \mathrm{C}$ in the tectonite to $800-850^{\circ} \mathrm{C}$ in the upper mylonite (Van der Wal and Vissers, 1993; Garrido et al., 2011). The mean grain size of olivine and pyroxene decreases progressively from $\sim 1 \mathrm{~mm}$ in 
the tectonite to 50-300 $\mu \mathrm{m}$ in the upper mylonite, consistent with the decrease in temperature recorded during deformation at high strain (Fig.2; Van der Wal and Vissers, 1996; Précigout et al., 2007). A syn-tectonic pressure of around 1.8-2.0 GPa has been documented in the mylonite (Garrido et al., 2011).

\section{Mineral fabric and modal composition}

\subsection{Lattice preferred orientations (LPOs) and fabric strength}

We measured LPOs of olivine and pyroxenes in 37 peridotite samples from the tectonite to the upper mylonite using Electron Backscatter Diffraction (EBSD). Olivine LPOs are displayed in Figure 3, the orthopyroxene and clinopyroxene LPO pole figures are provided in data repository. In Figure 4, we illustrate the general variation in olivine fabric across the Ronda shear zone using both the axis pole figures and plots of the orientation of maximum density. In the upper tectonite and lower mylonite, the olivine LPOs generally show a [100] maxima parallel to the lineation (X), a [010] maxima normal to the foliation (Z) and a [001] maxima normal to the lineation in the foliation plane. This flow-parallel [100]-axis olivine LPO is typical of A-type fabric, which is common in lithospheric peridotite and results from the dominance of the (010)[100] dislocation slip system (e.g., Zhang and Karato, 1995). In contrast, many samples of the upper mylonite preserve LPOs with [100] and [001] axes normal and parallel to the lineation, respectively, while the [010] axis remains normal to the foliation. This flow-normal [100]-axis olivine is typical of B-type fabric (Jung and Karato, 2001). It appears locally within outcrops that display weak LPOs in the upper mylonite and progressively overprints the A-type fabric in the mylonitic domain over a distance of 300 meters. This overprinting gives rise to a transitional [010]-fiber fabric - which we refer to as A/B-type fabric - characterized by [100] and [001] axes girdles within the foliation plane (Figure 4B and 4C). The overall transition from dominantly A-type to B-type fabric is well 
illustrated by the transition from generally lineation parallel [100] maximum to lineation perpendicular [100] maximum shown in Figure 4D.

Comparison of Figures 4D and 4E illustrates that the transition in olivine fabric type is also correlated with variations in fabric strength. For this analysis we used both the $\mathrm{M}_{\text {index }}$ (Skemer et al., 2005) and $\mathbf{J}_{\text {index }}$ (Bunge, 1982). Although the $\mathbf{M}_{\text {index }}$ and $\mathrm{J}_{\text {index }}$ provide very similar information (Schaeben, 2007; Skemer and Karato, 2007), they rely on different parameters. Thus, we present both indices to document the olivine fabric in Ronda. In the upper tectonite, the $\mathrm{M}_{\text {index }}$ and $\mathrm{J}_{\text {index }}$ are nearly constant with a value of $0.1 \pm 0.05$ and $3.8 \pm$ 0.3 , respectively. Upon entering the mylonitic domain, both the $\mathrm{M}_{\text {index }}$ and $\mathrm{J}_{\text {index }}$ increase progressively up to 0.325 and 8.7 in the lower mylonite, and then decrease down to $0.05 \pm$ 0.04 and $2.4 \pm 0.4$ in the upper mylonite, respectively. With respect to the fabric types, dominantly A-type fabrics are observed where the fabric strength remains constant then progressively increases. In contrast, the location where the fabric strength starts decreasing in the lower mylonite corresponds to where the transitional A/B-type LPO is observed. Finally both the $\mathrm{M}_{\text {index }}$ and $\mathrm{J}_{\text {index }}$ are lowest where B-type fabric is observed near the peridotite/crust contact. Our findings thus document that the transition from A-type to B-type fabric is spatially correlated with the transition to lower fabric strength in the mylonite.

\subsection{Misorientation axes and subgrain orientations}

To investigate the origin of B-type fabric in Ronda, we analyzed misorientation axes across olivine subgrain boundaries to constrain the dominant dislocation slip system(s) activated during deformation of the Ronda peridotite (e.g., Kruse et al., 2001; Mehl et al., 2003; Soustelle et al., 2009). Subgrain boundaries were not particularly abundant in the samples, especially where B-type fabric occurs. Nonetheless, we collected the subgrain misorientation data in samples throughout the Ronda shear zone. In Figure 5a, we show an 
example of subgrain boundary within a sample that developed B-type olivine fabric. The pole figure shows the variation in the orientation of axes along a transect shown in the micrograph. It first illustrates that the [100] axes are approximately normal to the subgrain boundary. Moreover, the [001] axes show little scatter, while the [100] and [010] axes show rotation on a misorientation axis close to [001]. Thus, although this sample shows B-type fabric, the character of the subgrain boundary is consistent with a tilt boundary formed predominantly by edge dislocations from the olivine (010)[100] slip system, i.e., the A-type slip system (Lloyd et al., 1997; Mehl et al., 2003).

In Figure 5b, we illustrate more examples of misorientation data across subgrain boundaries for samples from the tectonite, lower mylonite and upper mylonite that developed A-type, A/B-type and B-type fabric, respectively, as well as one sample that did not exhibit a well-defined fabric type. In each case, we find that the [100] axes are oriented approximately normal to the subgrain boundary. Furthermore, with the exception of sample 33, all of the samples that show a clear rotation signature exhibit smaller rotations of [001] or [010] relative to the other axes. These features suggest subgrain boundaries consistent with tilt boundaries comprised of (010)[100] or (001)[100] edge dislocations, similar to observations on high temperature peridotites that exhibit A-type fabric (e.g., Falus et al., 2011). Sample 33 shows a more complex orientation, however, the fact that the subgrain is normal to the [100] axis is inconsistent with either a twist or tilt boundary from the (010)[001] "B-type" slip system. We did not find any subgrains with misorientation axes close to the [100] axis, and hence consistent with the (010)[001] "B-type" slip system, even in samples from the upper mylonite that exhibit the olivine B-type fabric (Fig.5). Thus irrespective of the olivine fabric type, our misorientation dataset shows no evidence for a change in the character of the subgrains. We therefore conclude that B-type fabric did not result in intra-granular textures indicative of (010)[001] slip in Ronda. Furthermore, the observation of sub-structures indicative of 
(010)[100] slip in the mylonite indicates that these textures either formed synchronously with the formation of the B-type LPO - or that they were not overprinted by the later deformation event.

\subsection{Modal composition}

The relationship between modal composition of the peridotite and fabric strength is illustrated in Figure 6. Overall, the Ronda samples do not show a strong correlation between either the fabric type, or fabric strength and modal composition. We only discern a weak relationship showing that samples with the strongest B-type fabrics have low olivine content. However, for the discussion below, we emphasize that these samples are characterized by having generally high CPx content, rather than high OPx content.

\section{Discussion}

\subsection{B-type fabric in the laboratory and nature}

Differences in the geometry of olivine fabrics are generally related to transitions in the dominant slip system associated with changes in stress, pressure, temperature and water content (e.g., Katayama et al., 2004). Jung and Karato (2001) first documented B-type fabric in experimentally deformed olivine aggregates, and hypothesized that it formed due to the dominance of the (010)[001] slip system under high stresses with a combination of high water content and high confining pressure. However, over the last 10 years, at least five other experimental studies have shown that B-type fabric also forms under dry conditions over a wide range of pressures. (1) Holtzman et al. (2003), Kohlstedt and Holtzman (2009) and Qi et al. (2013) produced B-type fabric during general shear and torsional shear of fine-grained, partially molten olivine aggregates at low differential stress (below $150 \mathrm{MPa}$ ) and a confining pressure of $300 \mathrm{MPa}$. These authors concluded that the B-type fabric formed owing to the 
grain-scale effect of aligned melt pockets on the GBS component of deformation. (2) Sundberg and Cooper (2008) observed B-type fabric in fine-grained anhydrous harzburgite $(35-50 \%$ OPX) at low stress $(<200 \mathrm{MPa})$, moderate confining pressure $(1.5 \mathrm{GPa})$ and $1200^{\circ} \mathrm{C}$. Based on the grain size and rheological data, they concluded that B-type fabric formed during diffusion creep, although the stress exponents determined for the pyroxene-rich samples were statistically higher ( 1.8) than 1 (the theoretical value of $n$ for diffusion creep). (3) Jung et al. (2009) reported a change from A-type fabric to B-type fabric in dry dunite (with $3 \%$ OPX) with increasing confining pressure from 2.5 to $3.1 \mathrm{GPa}$ at relatively low stress $(\sim 150 \mathrm{MPa})$ and $1300^{\circ} \mathrm{C}$. (4) Ohuchi et al. (2011) documented the change from A-type to Btype fabric in dry dunite (without OPX) with increasing pressure from 5 to $7 \mathrm{GPa}$ at a temperature of $1200-1400^{\circ} \mathrm{C}$ (see also Couvy et al., 2004). The authors of the latter two studies concluded that B-type fabric arises from increasing confining pressure.

Olivine with B-type fabric has also been observed in naturally deformed peridotite. Mizukami et al. (2004) showed B-type fabric in olivine neoblasts of a dunite from the Higashi-Akaishi peridotite (North Japan), which deformed at $700-800^{\circ} \mathrm{C}$ in the presence of water at a pressure between 1.5 and 3.0 GPa. Similar B-type fabric has been also described in southwestern Japan within the Imono peridotite body (Tasaka et al., 2008). Skemer et al. (2006) documented B-type fabric in a peridotite mylonite from the Cima di Gagnone massif (Swiss Alps), which recorded deformation conditions of $800 \pm 175^{\circ} \mathrm{C}$ at undefined pressure; the presence of chlorite and tremolite indicated also the presence of water during deformation in the Cima di Gagnione massif. In constrast, Drury et al. (2011) identified B-type fabric in water-poor low-temperature $\left(<750^{\circ} \mathrm{C}\right)$ peridotite ultramylonite in the French Pyrenees (Etang de Lerz). Based on the results of Sundberg and Coopers's (2008) experimental study, Drury et al. concluded that B-type fabric formed during diffusion-accommodated GBS (i.e., diffusion creep) in the extremely fine-grained rocks. 


\subsection{Origin of B-type fabric in the Ronda shear zone}

In Ronda, the well constrained deformation conditions and well preserved spatial transition from A-type to B-type fabric provide an excellent opportunity to evaluate the processes responsible for B-type fabric under geologic conditions. For the Ronda mylonite, several of the proposed mechanisms are relatively easy to rule out. First, a pressure-induced transition to B-type fabric can be ruled out based on petrologic data, as the A-type to B-type transition is observed in rocks that deformed during exhumation with pressure decreasing below 2.5 GPa (Garrido et al., 2011). Second, the low-temperature conditions of deformation exclude the possibility of B-type fabric produced in the presence of melt.

The role of water on the fabric transition is more problematic to assess, partly due to the subsequent alteration (serpentinization) of the rocks, but several observations suggest that the water concentration in olivine was relatively low. First, extrapolation of the Arrhenius relation for $\mathrm{H}$ concentration in olivine (Zhao et al., 2004) indicates a solubility of $\sim 460 \mathrm{H} / 10^{6} \mathrm{Si}$ at $\sim 800^{\circ} \mathrm{C}$ and $2 \mathrm{GPa}$; this value includes the multiplication factor of 3.5 suggested by FTIR calibration measurements of water in olivine (Bell et al., 2003). For comparison with the fabric diagram of Katayama et al. (2004), which does not include the factor of 3.5, the water solubility is $\sim 130 \mathrm{H} / 10^{6} \mathrm{Si}$, falling within the A-type fabric regime. Second, no chlorite or amphibole is observed in the Ronda mylonite; the thermal stability of chlorite is $\sim 800^{\circ} \mathrm{C}$ at 2 GPa (Hacker et al., 2003). Thus even though some water can remain dissolved in nominally anhydrous minerals at water activities that are too low to stabilize hydrous phases, the value for $\mathrm{H}$ solubility in olivine should be considered a maximum. Third, neither of the other "water-induced" olivine fabrics (i.e., Type-E or Type-C; Katayama et al., 2004) are observed in the transitional region of the Ronda mylonite where A/B-type fabric occurs. While uncertainties remain on the temperature and stress dependence of the fabric transitions at low 
water contents (c.f. Karato et al., 2008), these arguments suggest that the B-type fabrics in Ronda are not produced by diffusion/advection of water from the overlying crust into the mylonite.

By process of elimination, consideration of experimental results suggests that the transition to B-type fabric in Ronda occurs owing to an enhancement of grain size sensitive deformation mechanism. This hypothesis is further supported by two observations: (1) analysis of misorientation axes across subgrains indicate a dominance of the A-type slip system in samples that exhibit both A-type and B-type fabrics (Fig.5), suggesting that the fabric transition did not occur due to a change in the dominant slip system. (2) The overprinting of A-type fabric by B-type fabric is spatially correlated with a decrease of both $\mathrm{M}_{\text {index }}$ and $\mathrm{J}_{\text {index }}$, i.e., fabric strength, in the highest strain regions of the shear zone (Fig.4). The increase of fabric strength upon entering the shear zone suggests that dislocation creep dominated in the A-type fabric domain. However, if dislocation creep remained the dominant deformation mechanism in the core of the Ronda shear zone (upper mylonite), we would expect increasing, or constant fabric strength with increasing finite strain (e.g., Silver et al., 1999; Bystricky et al., 2000; Warren et al., 2008). In contrast, deformation within the inner shear zone is characterized by decreasing $\mathrm{M}_{\text {index }}$ (and $\mathrm{J}_{\text {index }}$ ) with increasing strain, suggesting a deformation mechanism dominated by grain size sensitive processes (Warren and Hirth, 2006; Précigout et al., 2007).

By integrating results from both laboratory and geological studies, we propose that the B-type fabric in the Ronda mylonite forms as a result of GBS. The interface-controlled diffusion mechanism proposed by Sundberg and Cooper (2008) - which is contingent on the presence of OPx - is possible. However, our analysis of relationships between the modal composition and fabric strength indicate that the samples with the strongest B-type fabric contain abundant CPx, rather than OPx (Fig. 6); this observation is inconsistent with the 
Sundberg and Cooper mechanism owing to the additional compositional components involved with diffusion creep in the presence of $\mathrm{CPx}$ (i.e., Al, Ca). Furthermore, the results of Kohlstedt and Holtzman (2009) on partially molten dunite indicate that OPx is not required to produce B-type fabric during grain size sensitive creep. Based on these observations, we speculate that the GBS sliding process itself is responsible for the evolution of LPO in these samples.

We envision that GBS may produce B-type fabric via rigid rotation of grains "guided" by the orthorhombic olivine habit, resulting in alignment of the long [001] axes in the flow direction and alignment of the short [010] axes normal to the shear plane. Indeed, coaxial deformation experiments on olivine + clinopyroxene aggregates (Miyakazi et al., 2013) conducted at high temperature and room pressure indicate that GBS on specific boundaries (in conjunction with a shape preferred orientation) may produce LPO (mostly A-type fabric). Although a shape preferred orientation is observed in the mylonite (e.g., Figure 2), posttectonic serpentinization of our samples makes statistical assessment of the details of shapepreferred orientation and grain boundary microstructures problematic. Furthermore, the conditions of Miyazaki et al. experiments $\left(1150-1385^{\circ} \mathrm{C}\right.$, room pressure, coaxial shear) are quite different from those in the Ronda mylonite $\left(850^{\circ} \mathrm{C}, 2 \mathrm{GPa}\right.$, non-coaxial shear); hence direct comparisons are not straightforward. Finally, whereas Miyazaki et al. (2013) documented GBS accommodated by diffusional creep, the subgrain development and grain size reduction by dynamic recrystallization shown in the Ronda samples provide evidence for dislocation mobility, suggesting the dominance of DisGBS in the mylonite (Précigout et al., 2007). Thus, whereas the Miyazaki et al. results demonstrate LPO formation during diffusion accommodated GBS (i.e. diffusion creep), we infer that the B-type fabric formed during DisGBS in Ronda. 


\subsection{Deformation mechanism(s) in the Ronda shear zone}

To further assess the dominant deformation mechanisms under conditions where B-type fabric formed in the Ronda shear zone, we use deformation mechanism maps (DMM) constructed using olivine flow laws. As shown in Figure 7, at deformation conditions of $850^{\circ} \mathrm{C}$ and $2 \mathrm{GPa}$ constrained for the upper mylonite (Garrido et al., 2011), and a recrystallized grain size between 50 and $300 \mu \mathrm{m}$ (Précigout et al., 2007), extrapolation of laboratory flow laws indicate deformation conditions either near the boundary between the DisGBS and diffusion creep regimes (Fig. 7A: based on flow laws from Hirth and Kohlstedt, 2003) or within the DisGBS regime (Fig. 7B: based on flow laws from Hansen et al., 2011). In both cases, the DMMs predict DisGBS limited by GBS - instead of DisGBS limited by dislocation motion on the easy-slip system (e.g., Warren and Hirth, 2006). Our microstructural evidence for dislocation mobility supports the interpretation that the mylonite deformed by DisGBS instead of diffusion creep. The spatial correlations between the fabric strength and fabric type also suggest that strain localization in the mylonite resulted from a transition from dislocation creep (preserved in the tectonite) to DisGBS, such as proposed in Précigout et al. (2007).

Nonetheless, guided by insights from recent rheological experiments (Hansen et al., 2011 ; 2012), we highlight where our interpretations remain ambiguous owing to a lack of - or conflicting - experimental data. First, the interpretation that the Ronda tectonite deformed by dislocation creep is inconsistent with the DMM constructed using the DisGBS flow law from Hansen et al. (Fig.7D). In addition, for a temperature of $850{ }^{\circ} \mathrm{C}$, the Hansen et al.'s flow law predicts only a modest difference (approximately a factor of three) between the strain rate of the mylonite with a grain size of $\sim 100 \mu \mathrm{m}$ and that for the tectonite with a grain size of $\sim 1$ $\mathrm{mm}$ (Fig. 7B); this is inconsistent with the observation of significant strain localization into the mylonite (e.g. Vissers et al., 1997). Second, while our interpretation is generally 
consistent with the DMM constructed using the flow laws of Hirth and Kohlstedt (Fig. 7C), which predict a larger difference in strain rate for the mylonite and tectonite (Fig. 7A), the predicted magnitude of strain rate $\left(\sim 5.10^{-15} \mathrm{~s}^{-1}\right)$ is low for a shear zone (e.g. Vissers et al., 1997). Third, high temperature deformation experiments on olivine aggregates in the DisGBS regime do not produce B-type fabric; rather A-type fabric is observed (Hansen et al., 2011; 2012). Fourth, a possible resolution of these apparent discrepancies is that either the diffusion creep or DisGBS process is enhanced by the presence of pyroxenes. Currently there are conflicting results on this topic. For example, the diffusion creep flow law for nominally melt free lherzolite (Zimmerman and Kohlstedt, 2004) is the same within error as that determined for olivine (Hirth and Kohlstedt, 2003). In contrast, the results of Sundberg and Cooper $(2008 ; 2010)$ suggest an enhancement of diffusion creep in the presence of OPx.

Thus, although our findings and recent experiments highlight GBS as an effective mechanism to generate a mineral fabric (B-type fabric in this study), our results illustrate that additional experimental and theoretical studies on the relationships between GBS and olivine fabric (in both the DisGBS and diffusion creep regimes) are needed to constrain the more general applicability of our results for the interpretation of strain localization and seismic anisotropy in the lithosphere, as well as how (or if) these processes are related to B-type fabric observed in high-pressure experiments (> $3 \mathrm{GPa}$ ) and/or hydrous peridotite.

\section{Conclusion}

Based on documentation of olivine LPO, fabric strength and subgrain misorientation axes, we interpret that the olivine B-type fabric in Ronda results from GBS, not from a transition in the dominant slip system, as traditionally proposed. Extrapolation of experimental flow laws indicates that GBS may contribute to the deformation over a wide range of conditions in the upper mantle. Thus, our results may have importance for the 
interpretation of upper mantle deformation processes through observation of seismic anisotropy. In any case, our observations highlight the need to further resolve the competing processes responsible for fabric transitions using a combination of analyses on both laboratory and naturally deformed samples.

\section{Acknowledgements}

We thank Dr. Karsten Kunze (ETH-Zürich, Switzerland) and Dr. Bjarne Almqvist (ETH-Zürich) for their help to get the LPO data and their fruitful discussions. We also thank Dr. Carlos J. Garrido (CSIC, Granada, Spain) for his help in getting samples from the Ronda peridotite. We are moreover grateful for helpful reviews of the manuscript from Dr. Lars Hansen and anonymous reviewers. This work was funded by NSF award EAR-0738880 and the ETH-Zürich (ETH Fellowship application FEL-01 09-3).

\section{References cited}

Balanyá, J.C., Garcia-Dueñas, V., Azañon, J.M., and Sánchez-Gómez, M. (1997). Alternating contractional and extensional events in the Alpujarride nappes of the Alboran Domain. Tectonics $16,226-238$.

Bell, D.R., Rossman, G.R., Maldener, J., Endisch, D., Rauch, F., 2003. Hydroxide in olivine: A quantitative determination of the absolute amount and calibration of the IR Spectrum. Journal of Geophysical Research 108, 2105, doi:10.1029/2001JB000679.

Bunge, H., 1982. Texture analysis in Materials Science. Mathematical Models: Butterworths, London, $593 \mathrm{pp}$.

Bystricky, M., Kunze, K., Burlini, L., Burg, J.-P., 2000. High Shear Strain of Olivine Aggregates: Rheological and Seismic Consequences. Science 290, 1564-1597.

Couvy, H., Frost, D.J., Heidelbach, F., Nyilas, K., Ungár, T., Mackwell, S., and Cordier, P., 2004. 
Shear deformation experiments of forsterite at $11 \mathrm{GPa}-1400^{\circ} \mathrm{C}$ in the multianvil apparatus. European Journal of Mineralogy 16, 877-889.

Drury, M.R., Avé Lallemant, H.G., Pennock, G.M., Palasse, L.N., 2011. Crystal preferred orientation in peridotite ultramylonites deformed by grain size sensitive creep, Étang de Lers, Pyrenees, France. Journal of Structural Geology 33, 1776-1789.

Falus, G., Tommasi, A., and Soustelle, V. (2011) The effect of dynamic recrystallization on olivine crystal preferred orientations in mantle xenoliths deformed under varied stress conditions. Journal of Structural Geology 33, 1528-1540.

Fliervoet, T. F., Drury, M.R., Chopra, P.N., 1999. Crystallographic preferred orientations and misorientations in some olivine rocks deformed by diffusion and dislocation creep. Tectonophysics $303,1-27$.

Garrido, C.J., Gueydan, F., Booth-Rea, G., Précigout, J., Hydas, K., Padró-Navarta, J.A., Marchesi, C., 2011. Garnet lherzolite and garnet-spinel mylonite in the Ronda peridotite: Vestiges of Oligocene backarc mantle lithospheric extension in the western Mediterranean. Geology 39, 927930.

Hacker, B.R., Abers, G.A., Peacock, S.M., 2003, Subduction factory 1. Theoretical mineralogy, densities, seismic wave speeds, and $\mathrm{H}_{2} 0$ contents. Journal of Geophysical Research 108, 2029, doi:10.1029/2001JB001127.

Hansen, L.N., Zimmerman, M.E., Kohlstedt, D.L., 2012. The influence of microstructure on the deformation of olivine in the grain-boundary sliding regime. Journal of Geophysical Research 117, B09201, doi:10.1029/2012JB009305.

Hansen, L.N., Zimmerman, M.E., Kohlstedt, D.L., 2011. Grain boundary sliding in San Carlos olivine: Flow law parameters and crystallographic-preferred orientation. Journal of Geophysical Research 116, B08201, doi:10.1029/2011JB008220.

Hirth, G., Kohlstedt, D.L., 2003. Rheology of the Upper Mantle and the Mantle Wedge: A view from the Experimentalists. Geophysical Monographs 138, 83-105. 
Holtzman, B.K., Kohlstedt, D.L., Zimmerman, M.E., Heidelbach, F., Hiraga, T., Hustoft, J., 2003.

Melt Segregation and Strain Partitioning: Implications for Seismic Anisotropy and Mantle Flow. Science 301, 1227-1230.

Ismaïl, W.B., Mainprice, D., 1998. An olivine fabric database: an overview of upper mantle fabrics and seismic anisotropy. Tectonophysics 196, 145-157.

Jung, H., Karato, S.-I., 2001. Water-induced Fabric Transitions in Olivine. Science 293, 1460-1463.

Jung, H., Mo, W., Choi, H., 2009. Deformation microstructures of olivine in peridotite from Spitsbergen, Svalbard and implications for seismic anisotropy. Journal of Metamorphic Geology $27,707-720$

Karato, S-I., Jung, H., Katayama, I., Skemer, P., 2008. Geodynamic Significance of Seismic Anisotropy of the Upper Mantle: New Insights from Laboratory Studies. Annual Review of Earth and Planetary Sciences 36, 59-95.

Katayama, I., Jung, H., Karato, S.-I., 2004. New type of olivine fabric from deformation experiments at modest water content and low stress. Geology 32, 1045-1048.

Kohlstedt, D.L., Holtzman, B.K., 2009. Shearing Melt Out of the Earth: An Experimentalist's Perspective on the Influence of Deformation on Melt Extraction. Annual Review of Earth and Planetary Sciences 37, 561-593.

Kruse, R., Stünitz, H., and Kunze, K., 2001. Dynamic recrystallization processes in plagioclase porphyroclasts. Journal of Structural Geology 23, 1781-1802.

Lloyd, G. E., Farmer, A. B., and Mainprice, D., 1997. Misorientation analysis and the formation and orientation of subgrain and grain boundaries. Tectonophysics $279,55-78$.

Mehl, L., Hacker, B.R., Hirth, G., Kelemen, P.B., 2003. Arc-parallel flow within the mantle wedge: Evidence from the accreted Talkeetna arc, south central Alaska. Journal of Geophysical Research $108,2375$.

Miyazaki, T., Sueyoshi, K., and Hiraga, T., 2013. Olivine crystals align during diffusion creep of Earth's upper mantle. Nature 502, 321-326.

Mizukami, T., Wallis, S.R., Yamamoto, J., 2004. Natural examples of olivine lattice preferred orientation patterns with a flow-normal a-axis maximum. Nature 427, 432-436. 
Nicolas, A., Christensen, N.I., 1987. Formation of anisotropy in upper mantle peridotites — a review, in: Fuchs, K., Froideveaux, C. (Eds.), Composition, Structure and Dynamics of the LithosphereAsthenosphere System. American Geophysical Union 16, pp. 111-123.

Ohuchi, T., Kawazoe, T., Nishihara, Y., Nishiyama, N., Irifune, T., 2011. High pressure and temperature fabric transitions in olivine and variations in upper mantle seismic anisotropy. Earth and Planetary Science Letters 304, 55-63.

Platt, J.P., Argles, T.W., Carter, A., Kelley, S.P., Whitehouse, M.J., Lonergan, L., 2003. Exhumation of the Ronda peridotite and its crustal envelope: constraints from thermal modelling of a P-T-time array. Journal of the Geophysical Society, London 160, 655-676.

Platt, J.P., Behr, W.M., 2011. Lithospheric shear zones as constant stress experiments. Geology 39, 127-130, doi: 10.1130/G31561.1.

Précigout, J., Gueydan, F., Gapais, D., Garrido, C.J., Essaifi, A., 2007. Strain localization in the subcontinental mantle - a ductile alternative to the brittle mantle. Tectonophysics 445, 318-336.

Précigout, J., Gueydan, F., 2009. Mantle weakening and strain localization: implications for the longterm strength of the continental lithosphere. Geology 37, 147-150.

Précigout, J., Gueydan, F., Garrido, C.J., Cogné, N., and Booth-Rea, G., 2013. Deformation and exhumation of the Ronda peridotite (Spain). Tectonics 32, 1011-1025.

Qi, C., Zhao, Y.-H., and Kohlstedt, D. L., 2013. An experimental study of pressure shadows in partially molten rocks. Earth and Planetary Science Letters 382, 77-84.

Ramsay, J. G., 1980. Shear zone geometry: a review. Journal of Structural Geology 2, 83-99.

Schaeben, H., 2007. Comment on "The misorientation index: Development of a new method for calculating the strength of lattice-preferred orientation" by Philip Skemer, Ikuo Katayama, Zhenting Jiang, Shun-Ichiro Karato. Tectonophysics 441, 115-117.

Silver, P., Mainprice, D., Ismaïl, W.B, Tommasi, A., Barruol, G., 1999. Mantle structural geology from seismic anisotropy, in: Fei, Y., Bertka, C.M., Mysen, B.O., (Eds.), Mantle Petrology: Field Observations and high Pressure experimentations: a tribute to Francis, R. (Joe) Boyd. The geochemical Society, Special Publication, $N^{\circ} 6$. 
Skemer, P., Katayama, I., Jiang, Z., Karato, S.-I., 2005. The Misorientation index: Development of a new method for calculating the strength of lattice-preferred orientation. Tectonophysics 411,157 167.

Skemer, P., Katayama, I., Karato, S-I., 2006. Deformation fabrics of the Cima di Gagnone peridotite massif, Central Alps, Switzerland: evidence of deformation at low temperatures in the presence of water. Contribution to Mineralogy and Petrology 152, 43-51.

Skemer, P., Karato, S.-I., 2007. Reply to Comment on "The Misorientation index: Development of a new method for calculating the strength of lattice-preferred orientation". Tectonophysics 441, 119 120.

Soustelle, V., Tommasi, A., Bodinier, J.L., Garrido, C.J., Vauchez, A., 2009. Deformation and Reactive Melt Transport in the Mantle Lithosphere above a Large-scale Partial Melting Domain: the Ronda Peridotite Massif, Southern Spain. Journal of Petrology 50, 1235-1266.

Sundberg, M., Cooper, R.F., 2008. Crystallographic preferred orientation produced by diffusional creep of harzburgite: Effects of chemical interactions among phases during plastic flow. Journal of Geophysical Research 113, B12208, doi: 10.1029/2008JB005618.

Sundberg, M., Cooper, R.F., 2010. A composite viscoelastic model for incorporating grain boundary sliding and transient diffusion creep; correlating creep and attenuation responses for materials with a fine grain size. Philosophical Magazine 90, 2817-2840, doi: 10.1080/14786431003746656.

Tasaka, M., Michibayashi, K., Mainprice, D., 2008; B-type olivine fabrics developed in the fore-arc side of the mantle wedge along a subducting slab. Earth and Planetary Science Letters 272, 747 757.

Van der Wal, D., Chopra, P., Drury, M., Fitz Gerald, J., 1993. Relationships between dynamically recrystallized grain size and deformation conditions in experimentally deformed olivine rocks. Geophysical Research Letters 20, 1479-1482.

Van der Wal, D., Vissers, R.L.M., 1993. Uplift and emplacement of upper mantle rocks in the western Mediterranean. Geology 21, 1119-1122.

Van der Wal, D., Vissers, R.L.M., 1996. Structural Petrology of the Ronda Peridotite, SW Spain: Deformation History. Journal of Petrology 37, 23-43. 
Vissers, R. L. M., Drury, M. R., Newman, J., Fliervoet, T. F., 1997. Mylonite deformation in the upper mantle peridotites of the North Pyrenean Zone (France): implications for strength and strain localization in the lithosphere. Tectonophysics 279, 303-325.

Warren, J. M., Hirth, G., 2006. Grain size sensitive deformation mechanisms in naturally deformed péridotites. Earth and Planetary Science Letters 248, 423-435.

Warren, J.M., Hirth, G., Kelemen, P.B., 2008. Evolution of olivine lattice preferred orientation during simple shear in the mantle. Earth and Planetary Science Letters 272, 501-512.

Zhang, S., Karato, S-I., 1995. Lattice preferred orientation of olivine aggregates deformed in simple shear. Nature 375, 774-777.

Zhao, Y.H., Ginsberg, S.B., Kohlstedt, D.L., 2004. Solubility of hydrogen in olivine: dependence on temperature and iron content. Contribution to Mineralogy and Petrology 147, 155-161.

Zimmerman, M.E., Kohlstedt, D.L., 2004. Rheological Properties of Partially Molten Lherzolite. Journal of Petrology 45, 275-298, doi: 10.1093/petrology/egg089. 


\section{Figure captions}

Figure 1 - Location, structural map and cross-section of the study area in the Ronda peridotite (Betic Cordillera, Southern Spain).

Figure 2 - Microstructures in thin section (in polarized light) across the Ronda shear zone. These micrographs illustrate the progressive grain size reduction from the tectonite to mylonite by the country rocks. In the latter, cm-scale elongated OPx highlight the stretching lineation. $\mathrm{Ol}=$ Olivine; $\mathrm{OPx}=$ Orthopyroxene. $\mathrm{X}=$ lineation; $\mathrm{Z}=$ Foliation pole .

Figure 3 - Lattice Preferred Orientation (LPO) of olivine across the Ronda shear zone. The samples are numbered from 1 (lowest strain sample) to 37 (highest strain sample) and located on the shear zone cross-section and in figure 1. Orientations of the [100], [010] and [001] axes are plotted in lower-hemisphere pole figures with respect to $\mathrm{X}$ (lineation) and Z (foliation pole) deformation axes. The sample number and number of grains analyzed are noted in regular at the top left and in italic at the bottom left of the [100] pole figure, respectively. We also displayed values of the M (Skemer et al., 2006) and J (Bunge, 1982) indexes. Isocontours and shading scale are multiples of uniform distribution. The data acquisition has been done manually over whole thin section, considering one measurement per grain. The analyzing conditions were $15 \mathrm{kV}$ of voltage, $1.85 \mathrm{~A}$ of intensity and a working distance of 35 $\mathrm{mm}$.

Figure 4 - Geometry of olivine LPO and fabric strength across the Ronda shear zone. A) Cross-section showing the position of samples that illustrate the transition from A- to B-type fabrics, including the transitional A/B-type fabric. B) Lower-hemisphere pole figures showing the orientation of maximum density of the [100], [010] and [001] axes in all samples. The 
grey shading (from white in the tectonite to black by the peridotite/crust contact) highlights the sample location on the cross-section. C) Olivine [100] and [001] pole figures summarizing the transition from A-type to B-type fabrics across the shear zone. Sample numbers are shown on the cross-section and the top left of the [100] pole figure. D) Azimuth of maximum density for [100] and [001] axes with respect to the lineation and distance from the peridotite/crust contact. From the tectonite to mylonite, the two axes show opposite behaviors, evolving from around $0^{\circ}$ (parallel to the lineation) to $90^{\circ}$ (normal to the lineation in the foliation plane) for the [100] axis, and from $90^{\circ}$ to $0^{\circ}$ for the [001] axis. E) Olivine fabric strength across the Ronda shear zone based on $\mathbf{M}_{\text {index }}$ (Skemer et al., 2006) and $\mathbf{J}_{\text {index }}$ calculations (Bunge, 1982), and using standard parameters from Ismaïl and Mainprice (1998). To compare the A-type/B-type fabric transition with the trend of fabric strength, we denote samples that show A-, A/B- and B-type fabrics with black circles, white squares in black circles and white squares, respectively. White dots indicate samples that do not show a clearcut fabric. The A-type/B-type transition is spatially correlated with a drop in fabric strength. $\mathrm{X}=$ lineation; $\mathrm{Z}=$ Foliation pole.

Figure 5 - Misorientation axis data across subgrain boundaries. A) Example of subgrain microstructure, LPO and misorientation data of a mylonitic sample that developed B-type fabric (sample \# 26, subgrain 1). EBSD data are shown in lower-hemisphere pole figure with respect to $\mathrm{X}$ (lineation) and $\mathrm{Z}$ (foliation pole). The dashed line in the pole figure shows the orientation of the subgrain boundary determined optically. B) Misorientation axis data across 7 sub-grain (sb) boundaries through the whole shear zone, including samples for which the fabric type is not clear-cut (sa. 1), A-type fabric (sa. 4), A/B-type fabric (sa. 15) or B-type fabric (sa. 26 (sb 2), 32 and 33). For each sample, we show a lower-hemisphere pole figure that includes EBSD data for the [100], [010] and [001] axes and the subgrain boundary. Pole 
figures are shown with respect to $\mathrm{X}$ and $\mathrm{Z}$. In all cases, the [100] axis is approximately normal to the subgrain boundary, the misorientation axis (minimum rotation) is close to parallel to the subgrain boundary plane, and the misorientations are consistent with tilt boundaries comprised of edge dislocations on the (001)[100] and (010)[100] slip systems, irrespectively to the olivine fabric.

Figure $6-\mathrm{M}_{\text {index }}$ of olivine LPO vs. modal composition of peridotite (in weight $\%$ ) across the Ronda shear zone. The symbols indicate the fabric type. In general, there is not a correlation between modal composition and fabric strength, or fabric type. However, there is an indication that the strongest B-type fabrics form in samples with the lowest olivine content (which is associated with relatively high CPx contents). Values and percentages of oxides are shown in table 1 of the supplementary material. $\mathrm{CPx}=$ clinopyroxene; OPx = Orthopyroxene; $\mathrm{Ol}=$ Olivine

Figure 7 - Olivine Deformation Mechanism Maps (DMM) for deformation conditions of the Ronda mylonite (A and $\mathrm{B}$ ) and tectonite (C and D), i.e., for a pressure of $2 \mathrm{GPa}$ and temperatures of $850^{\circ} \mathrm{C}$ and $1100^{\circ} \mathrm{C}$, respectively. The DMM displays the competing deformation mechanisms that control the rheology of olivine aggregates as a function of stress, grain size, strain rate, temperature and pressure. Here we calculate DMMs using four deformation mechanisms, as described in Warren and Hirth (2006): dislocation creep (disl.); DisGBS that includes both the easy-slip and GBS regimes (Warren and Hirth, 2006); diffusion creep (Diff.) and low-temperature plasticity. In A and C we use the DisGBS flow law from Hirth and Kohlstedt (2003), and in B and D we use the DisGBS flow law from Hansen et al. (2011). The temperature and pressure are chosen based on the temperature and pressure records in the Ronda mylonite (Garrido et al., 2011). Using the recrystallization 
piezometer of Van der Wal et al. (1993) and the recrystallized grain sizes in the Ronda mylonite (50-300 $\mu \mathrm{m}$; Précigout et al., 2007), extrapolations of both Hirth and Kohlstedt and Hansen et al. flow laws predict dominant GBS-limited DisGBS for the mylonite. For the tectonite, the deformation conditions are plotted using the Van der Wal et al. piezometer and a grain size of 1-3 mm. The dashed box in Figures 7A and 7B shows the predicted strain rate at the stress predicted by the mylonite grain size, but considering grain size of the protolith, i.e., the tectonite (e.g., Platt and Behr, 2011). The arrow illustrates the grain size reduction related to strain localization in the mylonite.

\section{Supplementary material}

Supplementary Table 1 - Whole-rock major elements, modal compositions (in weight \%) and fabric strength of the studied samples. Chemical analyzes have been performed at the Franklin \& Marshall College (Lancaster, PA., USA). The modes have been calculated from the CIPW method. $\mathrm{LOI}=$ loss of ignition; $\mathrm{Ol}=$ olivine; $\mathrm{Opx}=$ orthopyroxene; $\mathrm{Cpx}=$ clinopyroxene; $\mathrm{Spl}=$ Spinel $; \mathrm{M}=\mathrm{M}_{\text {index }} ; \mathrm{J}=\mathrm{J}_{\text {index }}$.

Supplementary Figure 1 - Set of lattice preferred orientation data for orthopyroxene and clinopyroxene within our 37 samples across the Ronda shear zone. Orientations of the [100], [010] and [001] axes are plotted in lower-hemisphere pole figures with respect to $\mathrm{X}$ (lineation) and $\mathrm{Z}$ (foliation pole) deformation axes. We took one measurement per grain. 
Figure 1
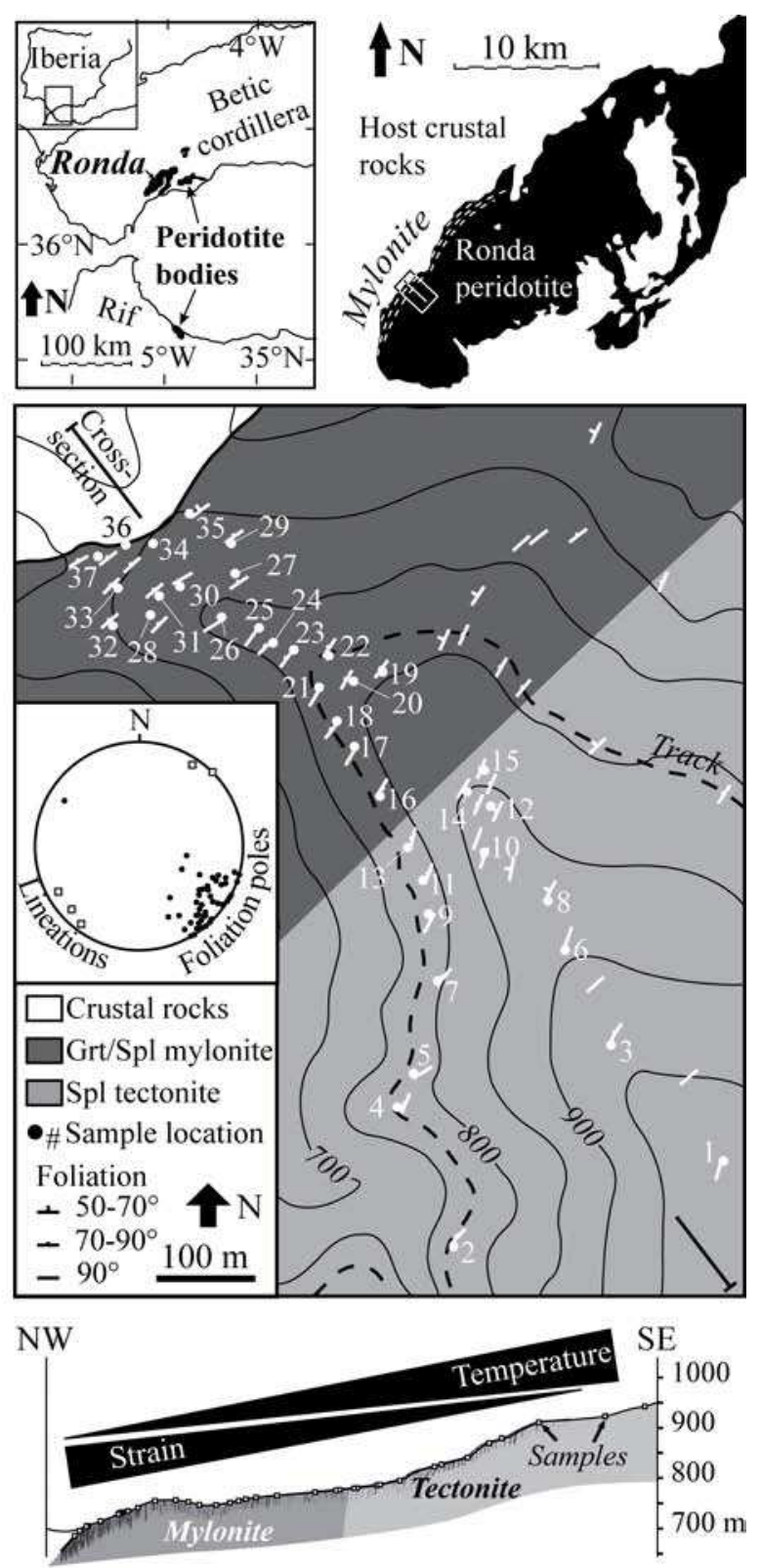
Figure 2
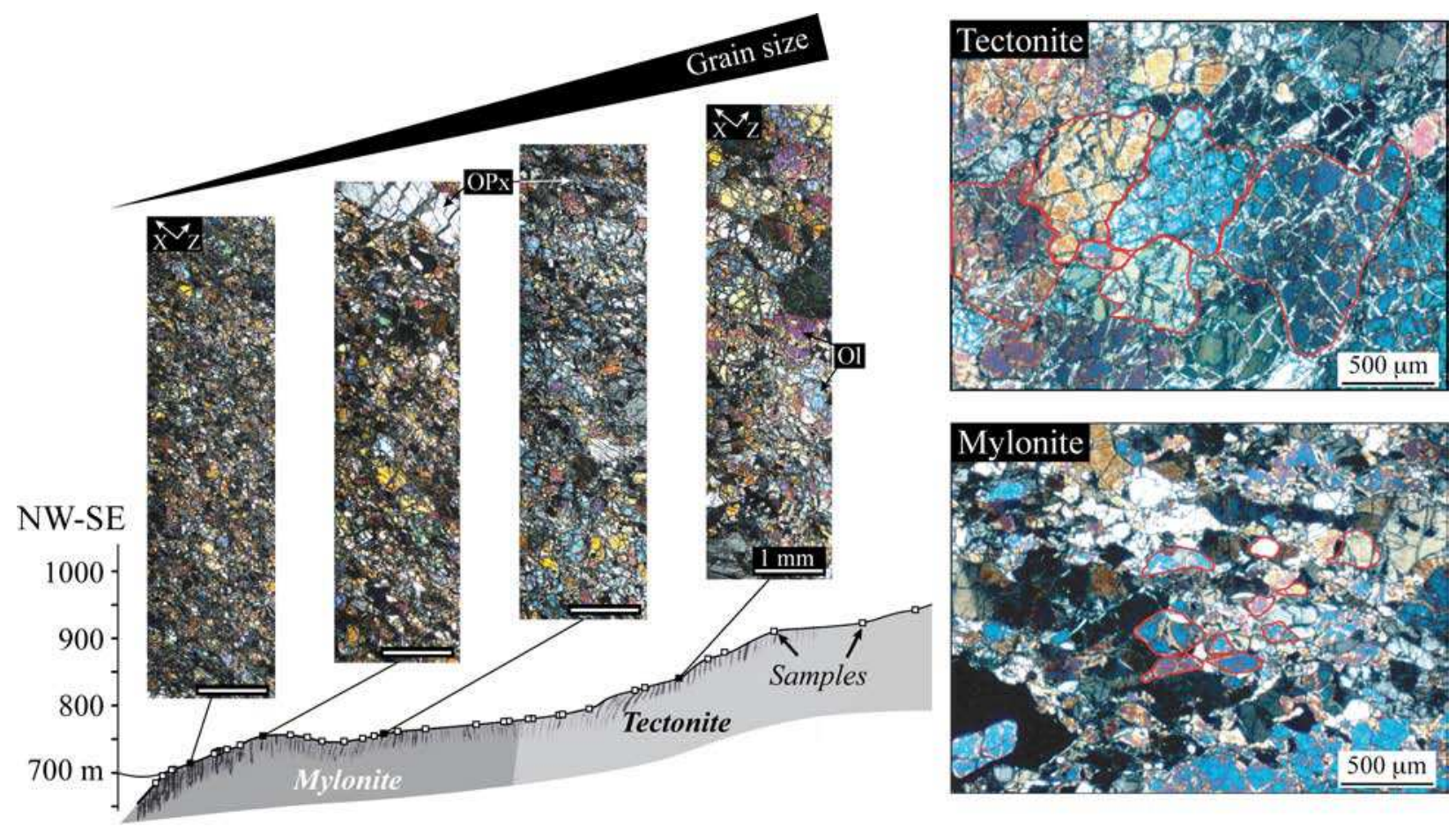
Figure 3
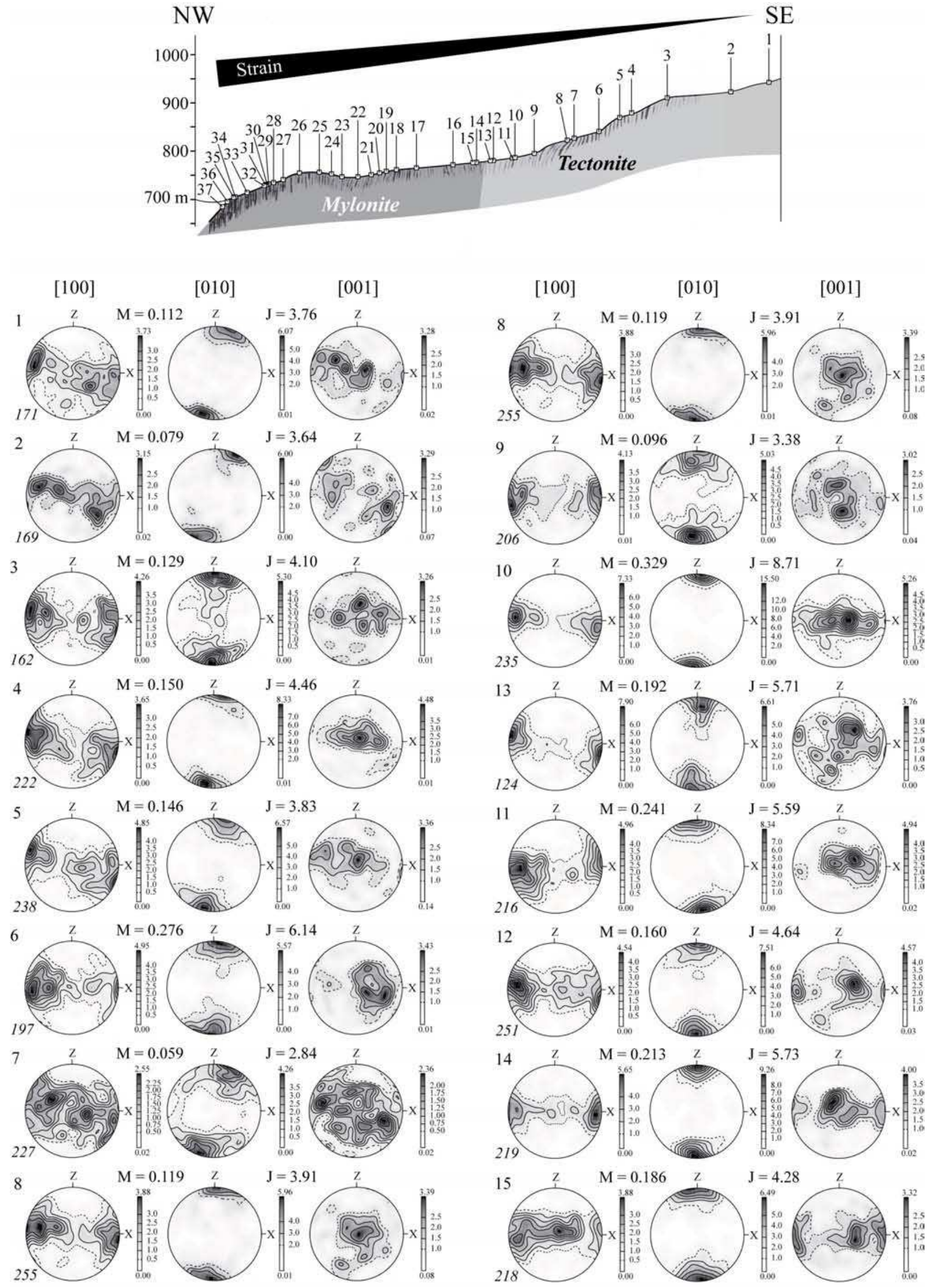
Figure 3 (continued)

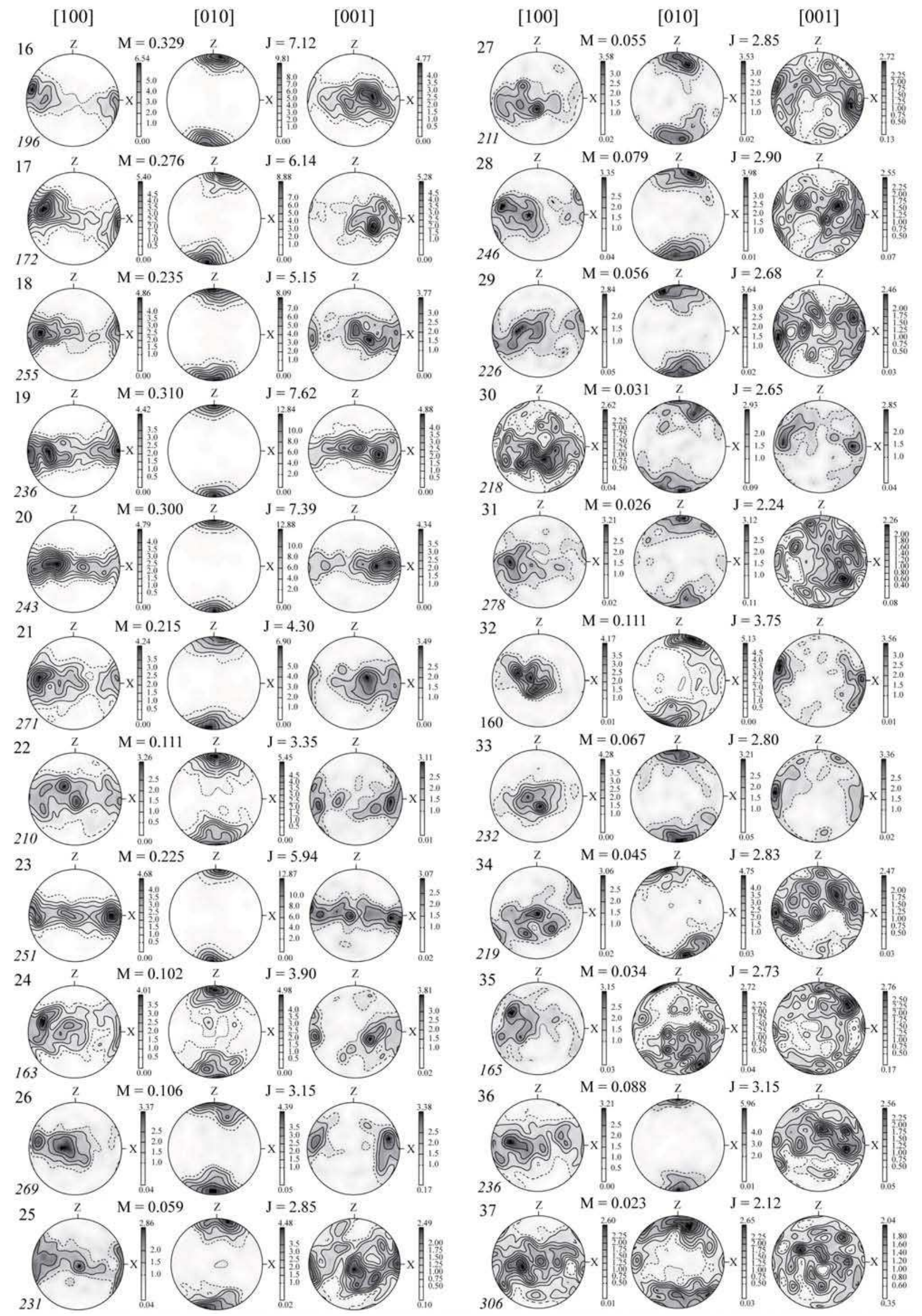


Figure 4

A)

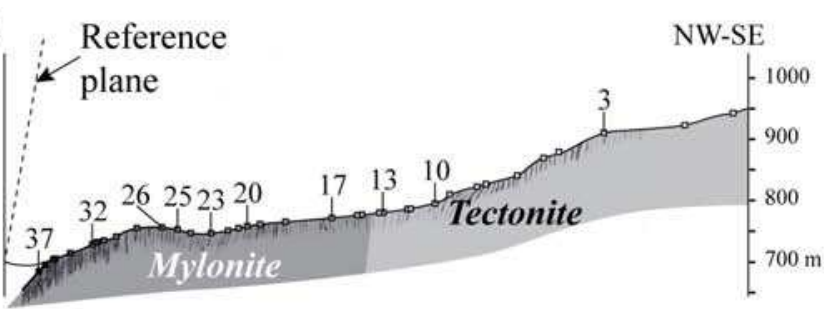

B)

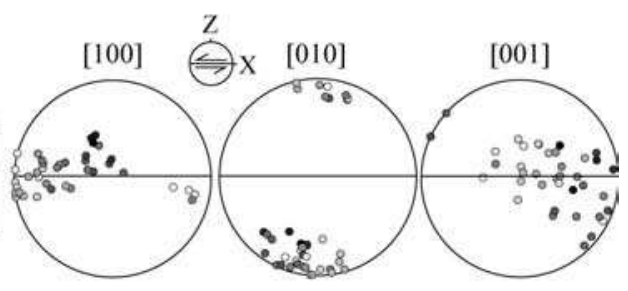

B-type fabric

A/B-type fabric

A-type fabric

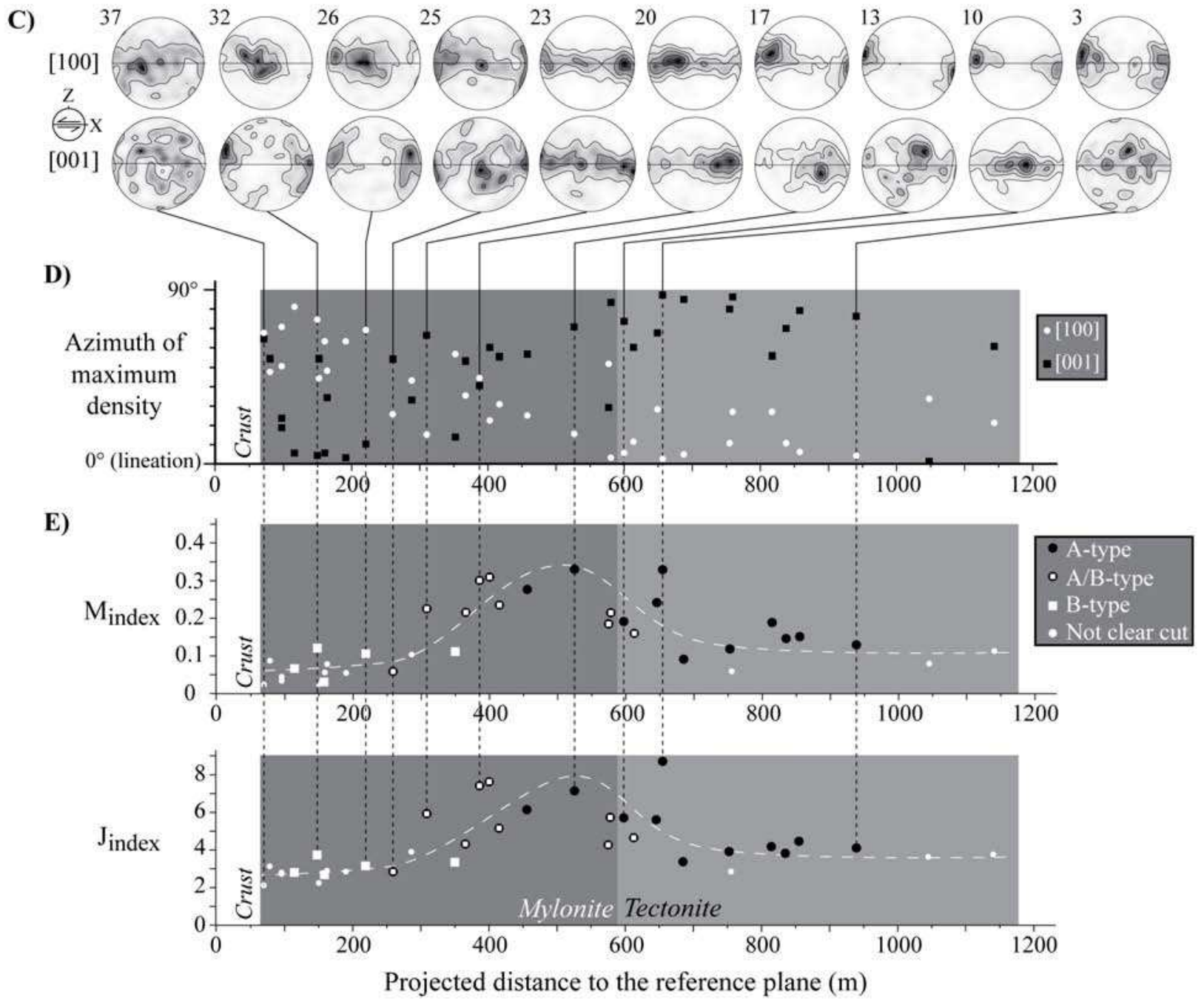




\section{Figure 5}
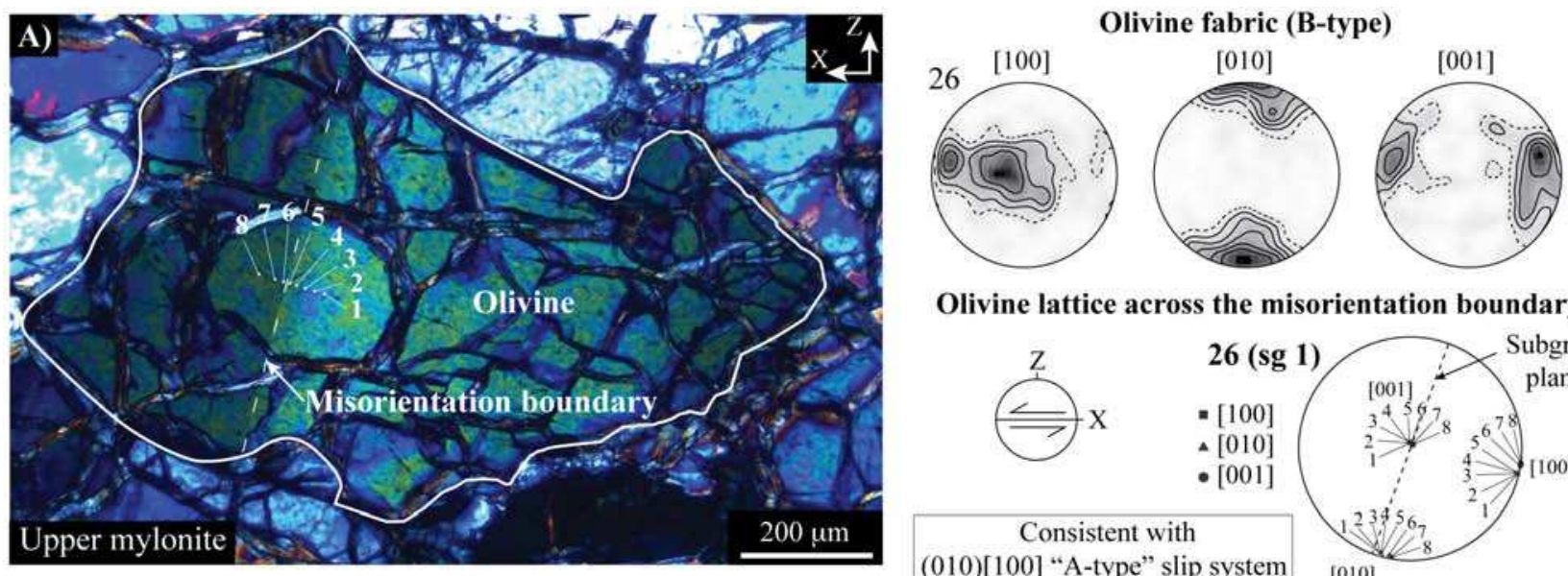

Olivine lattice across the misorientation boundary

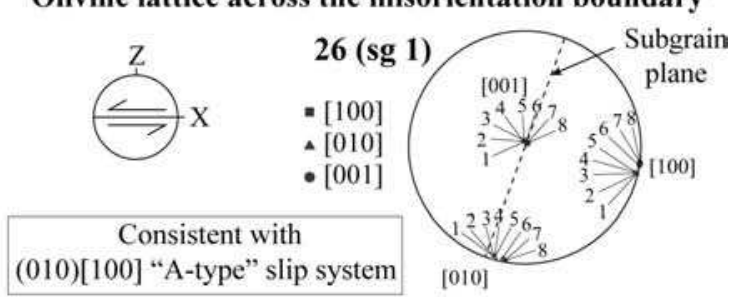

B)

Upper mylonite

Lower mylonite

Tectonite

Sa. 33

Sa. 32

Sa. 26 (sg 2)

Sa. 15 (sg 1)

Sa. 15 (sg 2)

Sa. 4

Sa. 1

(type B)

(type B)

(type B)

(type A/B)

(type A/B)

(type A)

(not clear-cut)
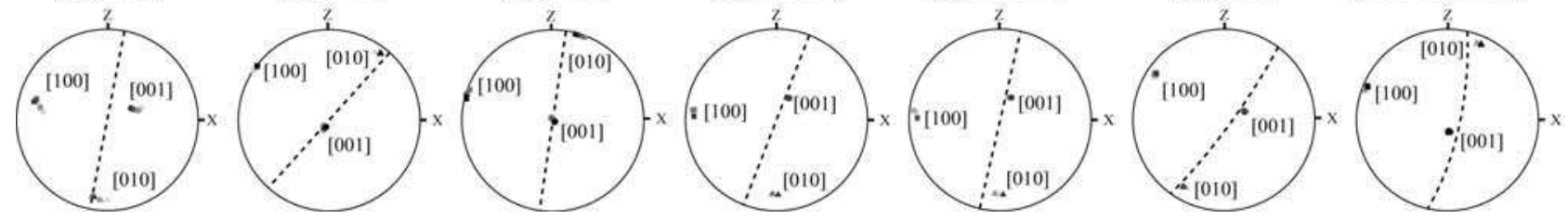
Figure 6

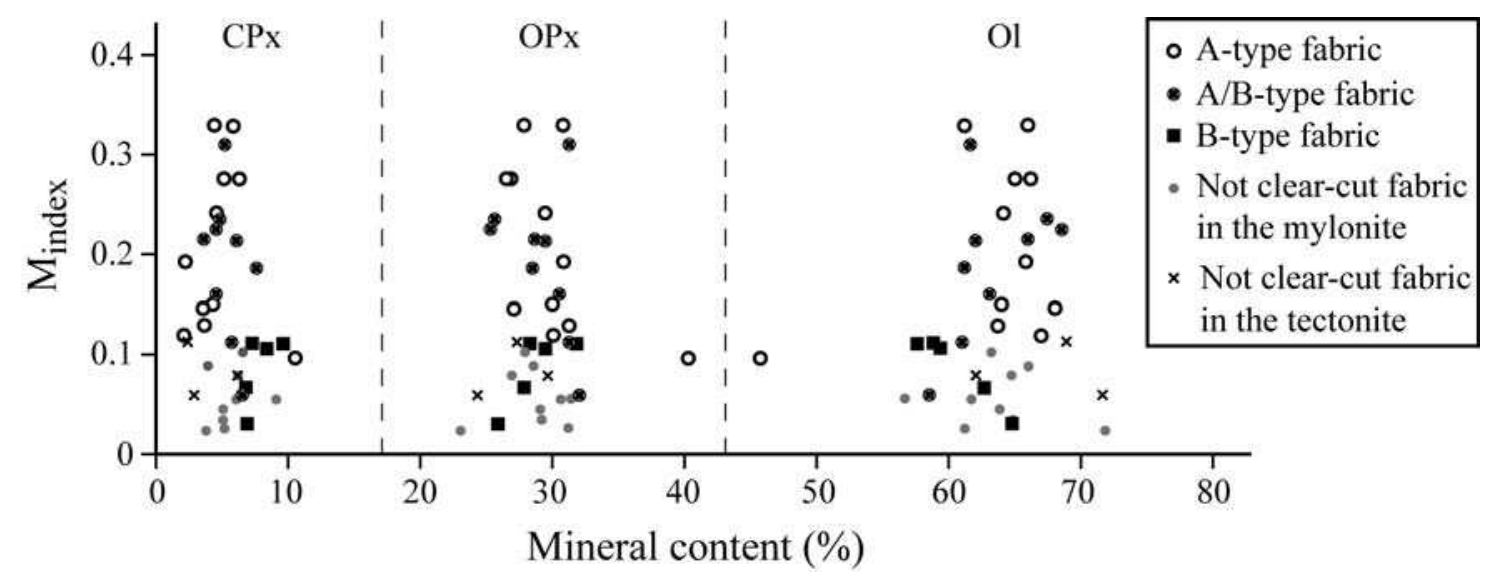


Figure 7

\section{Mylonite}
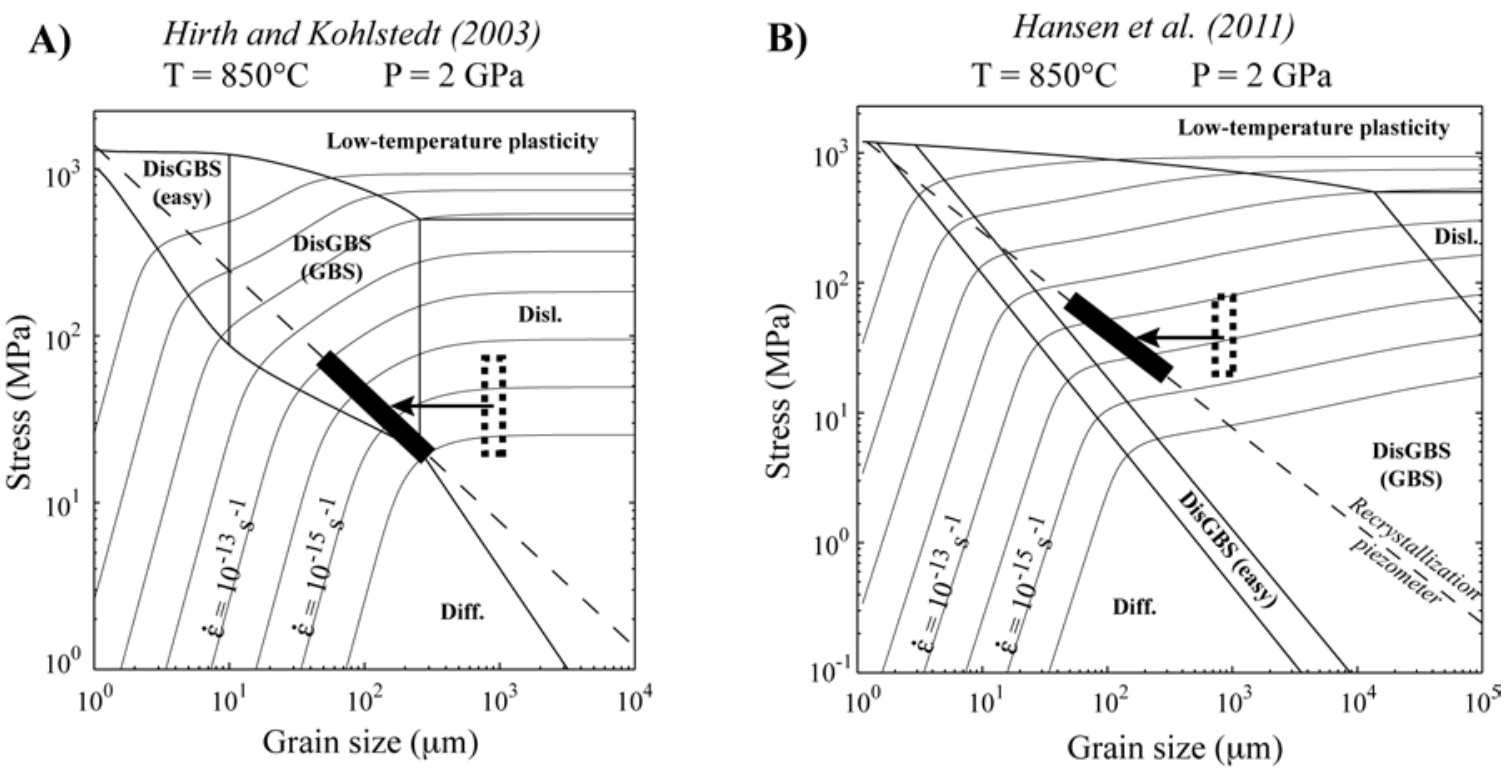

\section{Tectonite}
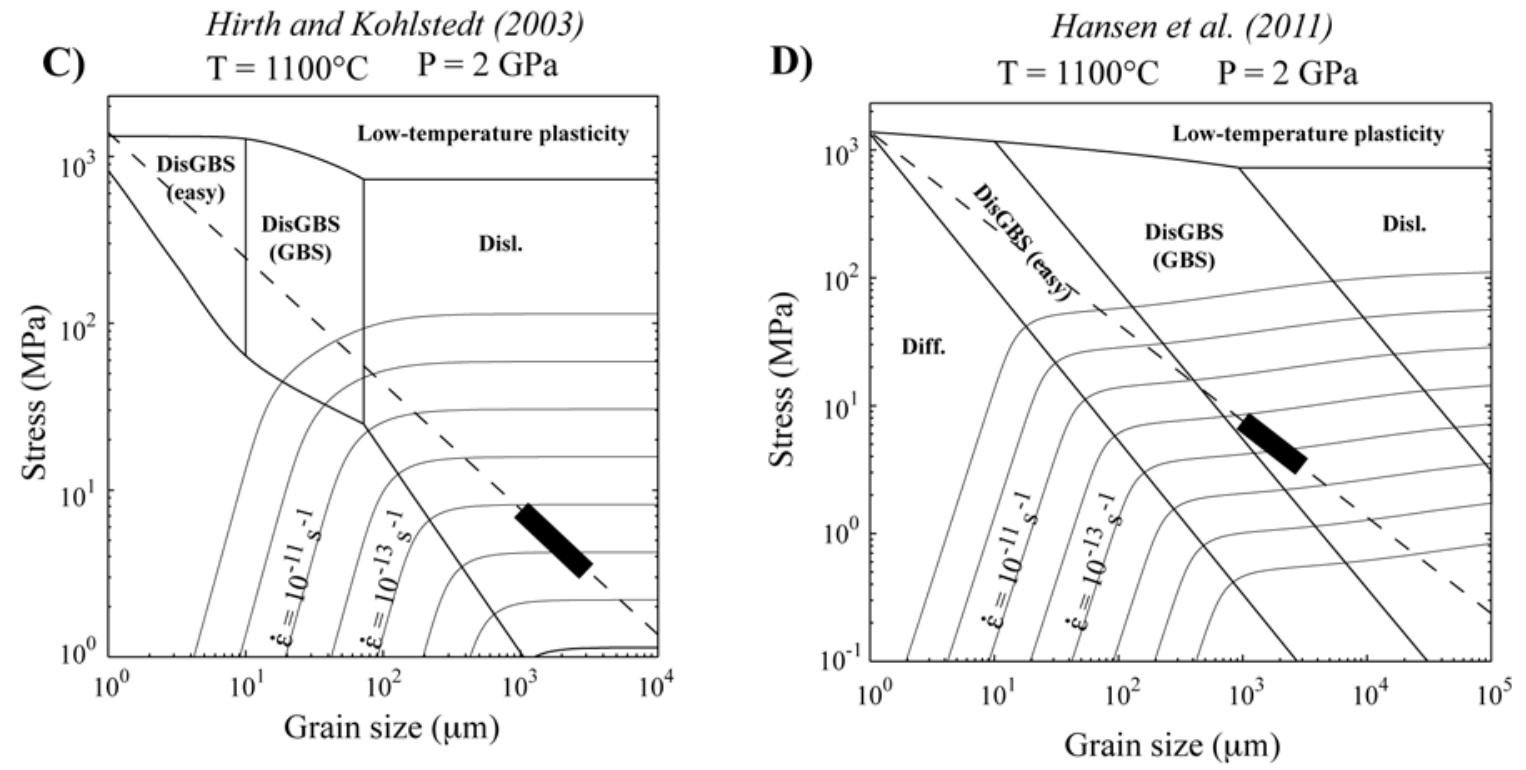
Supplementary figure 1

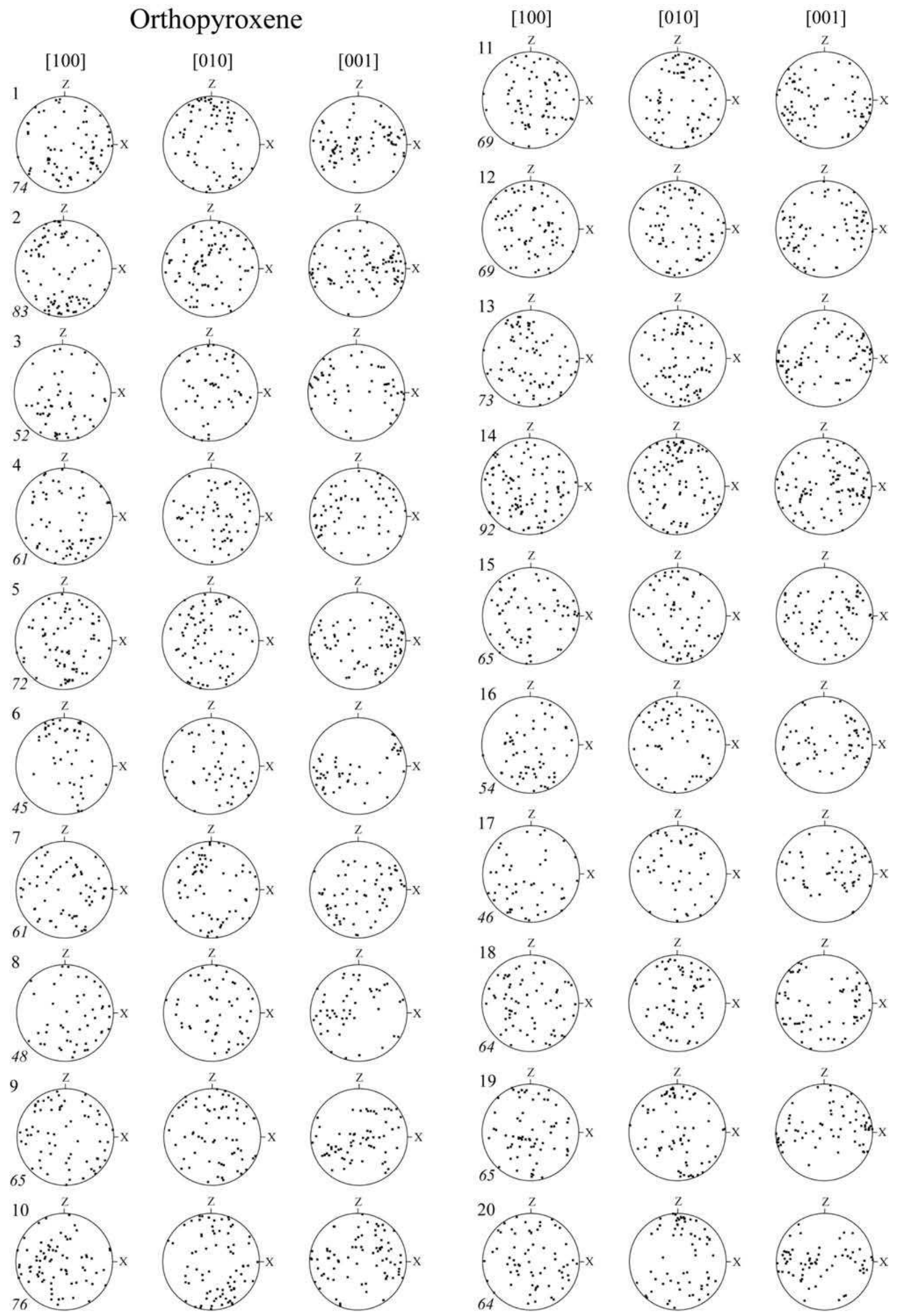


Supplementary figure 1 (continued)

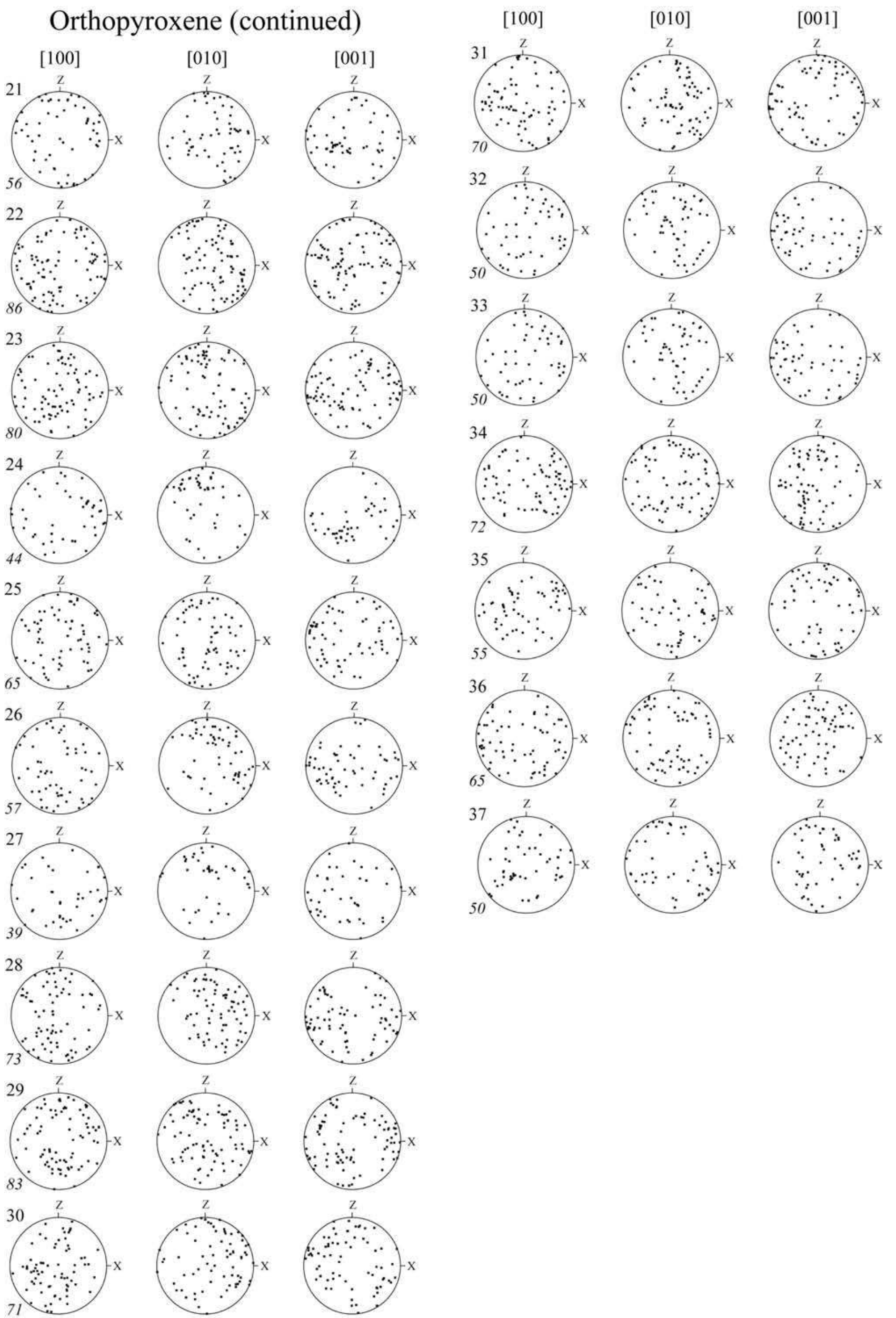


Supplementary figure 1 (continued)

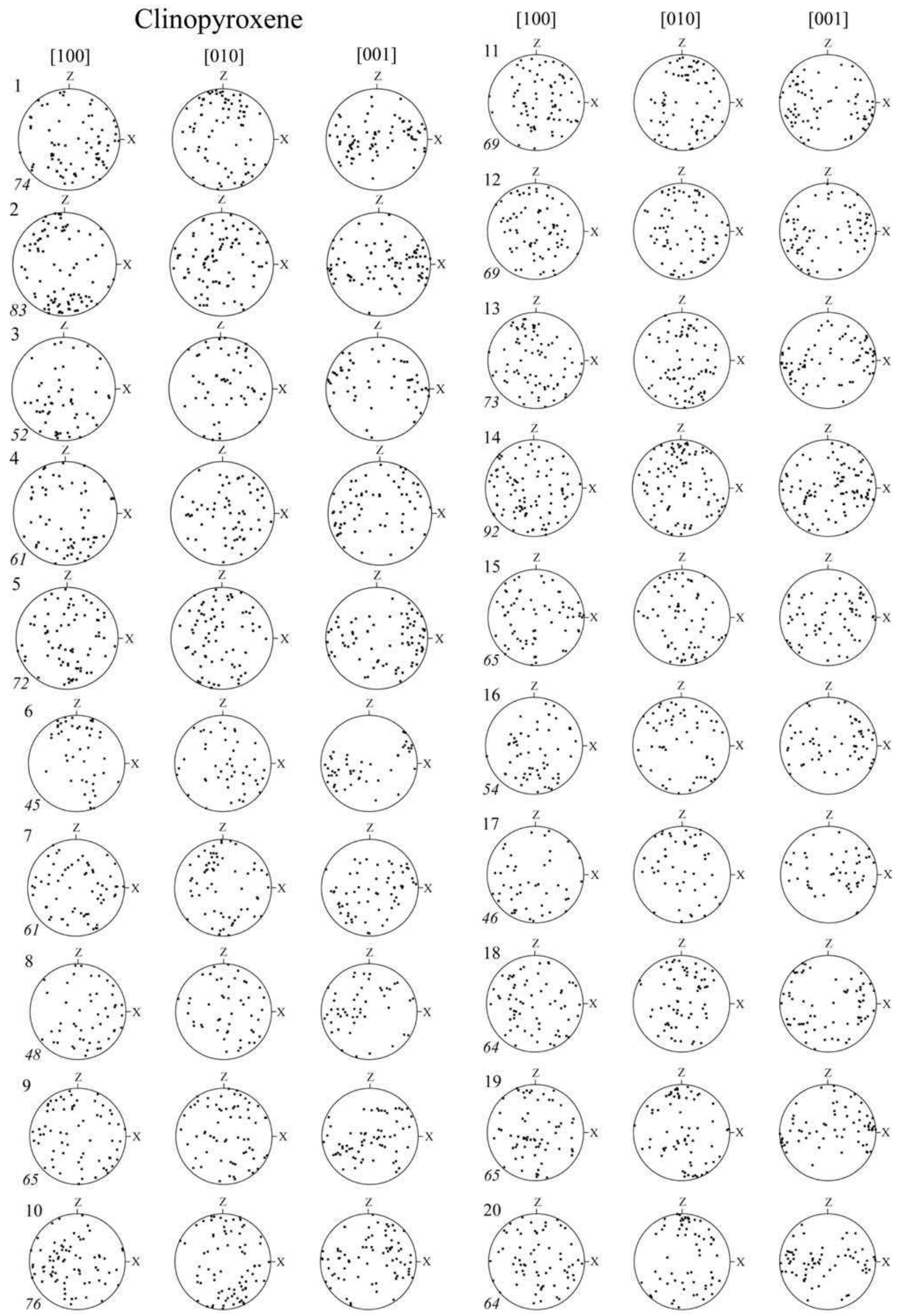


Supplementary figure 1 (continued)

Clinopyroxene (continued)

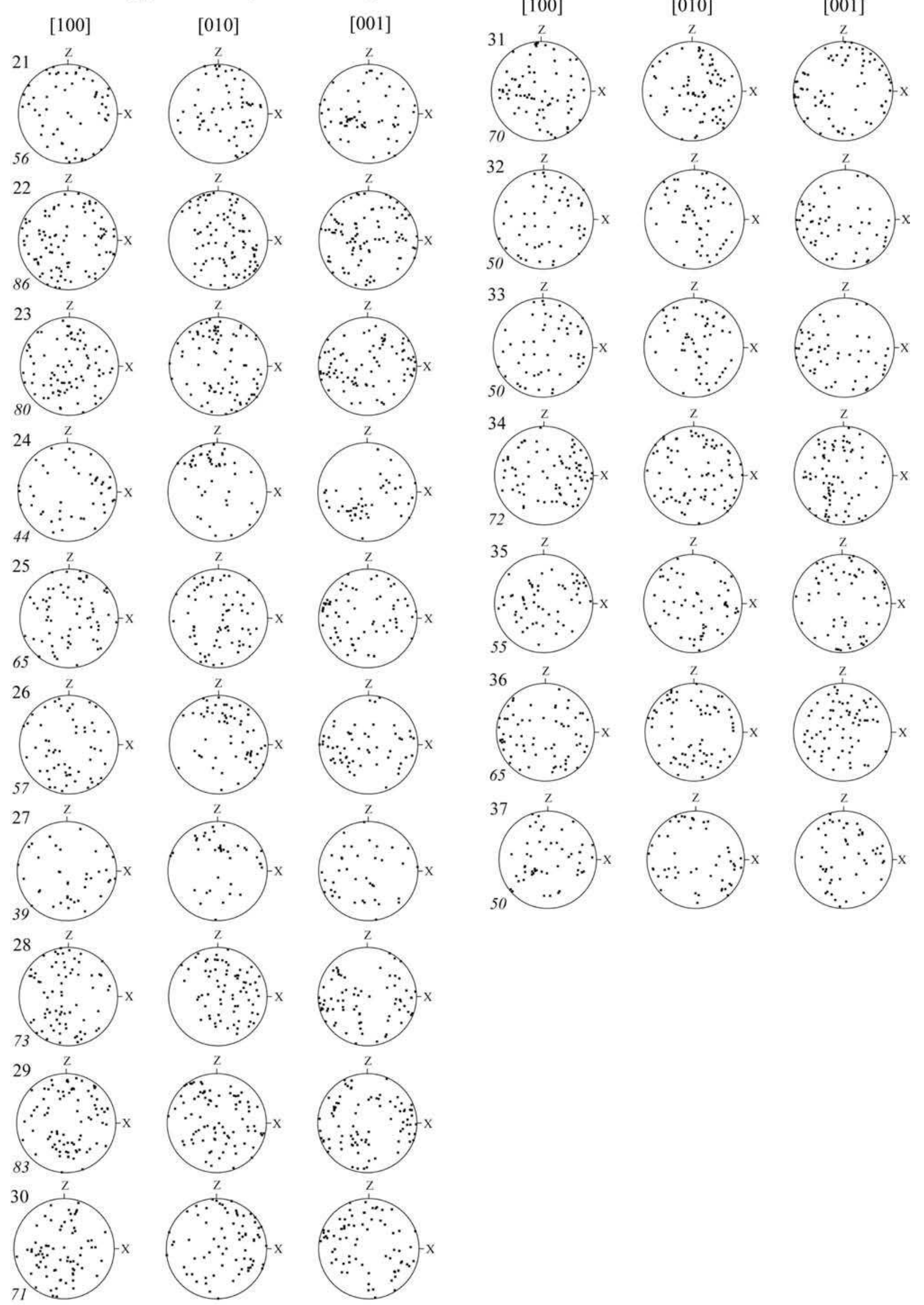




\section{Supplementary table 1}

\begin{tabular}{|c|c|c|c|c|c|c|c|c|c|c|c|c|c|c|c|c|c|c|c|}
\hline & & 2 & 3 & 4 & 5 & 6 & $I$ & 8 & 9 & 0 & 1 & 2 & 3 & 4 & 5 & 6 & 7 & 8 & 19 \\
\hline & & & & & 4 & & & 55 & 6 & 1 & 44 & 244 & 52 & 474 & 98 & 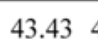 & 104 & 30 & 44.20 \\
\hline & 6 & 09 & 04 & 07 & .06 & 10 & 21 & 2 & 0.15 & 05 & 05 & 03 & 02 & 11 & 15 & .06 & .07 & 09 & 09 \\
\hline${ }_{2} \mathrm{O}_{3}$ & 10 & 2.77 & 1.79 & 2.28 & 1.79 & 2,38 & 60 & 1.11 & 4.32 & 2.81 & 2.28 & 21 & 35 & 3.03 & 3.53 & 2.22 & .74 & .60 & 2.60 \\
\hline${ }_{2} \mathrm{O}_{3}$ & 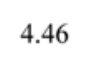 & 80 & 3.69 & 62 & 3.68 & 3.12 & 3.51 & 50 & 2.75 & 19 & 12 & 14 & 69 & 4.07 & .78 & 18 & .02 & 43 & 3.20 \\
\hline & & 1.74 & . & 4.56 & 4.43 & 3 & 5.31 & 3.62 & .72 & 4.22 & 4.25 & 10 & 38 & 4.31 & .63 & .06 & .45 & 67 & 4.86 \\
\hline & .64 & 40.66 & 42.92 & 42.07 & 43.42 & 41.65 & 43.40 & 44.51 & 35.60 & 40.81 & 42.04 & 41.774 & 44.29 & 40.383 & 38.77 & 42.49 & 40.82 & .13 & 40.84 \\
\hline & 94 & 2.47 & 1.56 & 1.77 & 1.54 & 2,08 & & & 4.44 & 2.36 & 93 & $20 ?$ & 1.03 & .45 & 93 & .83 & 2.58 & 00 & .08 \\
\hline & 04 & 0.16 & 0.07 & 0.10 & 0.06 & 0.13 & 0.09 & 0.01 & 0.20 & 0.13 & 0.10 & .03 & 01 & 0.14 & 0.23 & 0.10 & .11 & 11 & 0.14 \\
\hline & .00 & 0.01 & 0.00 & 0.00 & 0.01 & 0.00 & 01 & 000 & 0.02 & 0.00 & 00 & 00 & 00 & 0.01 & 0.00 & .00 & .00 & 00 & 0.01 \\
\hline & & 014 & 014 & 0.14 & 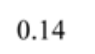 & 0.15 & & 0.14 & 0.14 & 0.15 & 0 & 015 & r & & 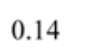 & 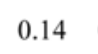 & 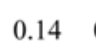 & 14 & 0.14 \\
\hline & & & & & & & & & & & & & & & & 0.28 & & 24 & .23 \\
\hline $\mathrm{r}_{2} \mathrm{O}_{3}$ & $J_{1}$ & $0.2 J$ & 0.27 & 0.24 & 0.20 & .19 & & & 0.2 & 0.20 & $0.2 \mathrm{~J}$ & 0.20 & 27 & 2 & 24 & .27 & .24 & 25 & 24 \\
\hline${ }_{2} \mathrm{O}_{5}$ & 01 & 0.01 & 0.00 & 0.00 & 0.00 & 0.00 & 0.01 & 0.00 & 0.01 & 0.00 & 0.02 & 0.00 & 01 & 0.01 & 0.01 & 0.00 & .00 & .01 & 0.01 \\
\hline & 98.98 & 98.93 & 99.09 & 99.10 & 99.31 & 3 & 98.99 & 99.02 & 99.02 & 99.16 & 99.24 & 99.259 & .98 & 98.629 & 98.63 & 99.07 & 98.559 & 98 & 8.65 \\
\hline${ }_{2} \mathrm{O}_{3}$ & 38 & 7 & 822 & 869 & 860 & 887 & 41 & 852 & 8.00 & 888 & 8.84 & 8.81 & 45 & 86 & 9.04 & 8.69 & .97 & 62 & 60 \\
\hline & 10.26 & & & 864 & 887 & & & & 681 & 817 & 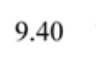 & & & & & 8.38 & & 25 & 7 \\
\hline & & & & & & & & & & & & & & & & & & & \\
\hline & 27.30 & 2 & 24 & 30.00 & 27.07 & 35 & & 04 & 25 & 30.79 & 473 & 563 & 87 & 532 & 28.502 & 27.85 & 26.532 & 25.71 & 31.27 \\
\hline$\%$ & 15 & 627 & 3.70 & 4.33 & 3.60 & 5.16 & 280 & 10 & 10.59 & 5.87 & 4.65 & 4.57 & 25 & (4) & 7.66 & 4.48 & 6.32 & .88 & 5.20 \\
\hline & & 205 & 132 & 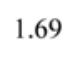 & 32 & 1.74 & & & 3.42 & 12 & & & & & & 1.66 & .12 & .95 & 1.91 \\
\hline & & & & & 0.146 & & & & & 0.329 & 0.241 & 0.160 & 0.192 & & 0.186 & 0.329 & 0.276 & 0.235 & 0.31 \\
\hline & & 3.64 & 4.10 & 446 & 3.83 & 6.14 & 2.84 & 301 & 3.38 & 071 & 550 & 464 & 5.71 & 5.73 & 4.28 & 7.12 & 6.14 & 5.15 & 7.62 \\
\hline & & & & & & & & & & & & & & & & & & & \\
\hline & 42 & 4 & 44.35 & 43.25 & 43.82 & 4 & 44.37 & 43.88 & 43.49 & 44.57 & 43.05 & 43.93 & 44.50 & 43.54 & 43.54 & 43.68 & 43.43 & 42. & \\
\hline $\mathrm{iO}_{2}$ & & 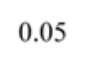 & ( & 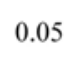 & 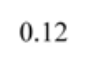 & 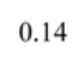 & . & . & (5) & 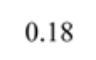 & 0.12 & 0.08 & 0.15 & 0 & م & 0.06 & 0.03 & . & \\
\hline & & & & & 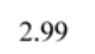 & 64 & & & & 3.74 & 3.20 & 2.94 & 4.11 & 3.36 & 2.64 & 2.01 & 1.85 & 1.8 & \\
\hline & & 37 & 90 & 3.98 & 55 & 73 & 50 & 95 & 3.84 & 3.58 & 4.26 & 3.74 & 2.81 & 3.86 & 4.50 & 4.63 & 4.69 & 3.47 & \\
\hline & & & & & & & & & & & & & & & 3.80 & 3.42 & 3.34 & 4. & \\
\hline & 64 & & 37.37 & & 40.24 & 39.25 & 37.88 & 40.69 & 40.73 & 37.94 & 40.40 & 41.09 & 38.67 & 39.80 & 41.92 & 42.54 & 43.28 & 43 & \\
\hline & & & & & & & & & & 3.39 & 2.67 & 4 & 2.80 & 2.65 & 2.05 & 1.69 & 1.66 & - & \\
\hline 2 & & & & & & & & & & 0.28 & 20 & 12 & 0.24 & 1 & 0.12 & 0.18 & 0.08 & 08 & \\
\hline & & 00 & 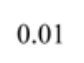 & 01 & 01 & 0.00 & & 01 & 00 & 0.00 & 0.00 & 0.00 & 0.00 & 0.00 & 0.00 & 0.00 & 0.00 & 0.00 & \\
\hline & & & & & & & & & & & & & & & & & 0.14 & 等 & \\
\hline & & & & & 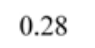 & 0.22 & 0.17 & 0.20 & & 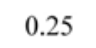 & 9 & 1 & 9 & 27 & 0.25 & 0.30 & 0.25 & . & \\
\hline 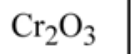 & & 27 & .22 & 0.25 & 0.22 & 0.27 & 0.21 & 0.23 & 0.23 & 0.22 & 0.21 & 0.28 & 0.26 & 0.22 & 0.27 & 0.30 & 0.27 & 0.2 & \\
\hline & & & & & & & & & & & & & & & & 0.00 & 0.01 & & \\
\hline & .12 & 98.82 & 99.18 & 99.12 & 98.94 & 98.67 & 98.65 & 98.77 & 98.72 & 99.23 & 98.69 & 98.96 & 99.14 & 99.08 & 99.33 & 98.95 & 99.04 & 98 & \\
\hline${ }_{2} \mathrm{O}_{3} \mathrm{~T}$ & 75 & 8.73 & 9.23 & 8.73 & 8.86 & 8.86 & 9.20 & 8.54 & 8.76 & 9.04 & 8.94 & 8.46 & 8.71 & 9.27 & 8.72 & 8.43 & 8.40 & 8. & \\
\hline & & & & & & & & & & & & & & & & 75 & 74 & & \\
\hline & & & 7 & 47 & 63.15 & 58 & 5 & 6 & 74 & 56.73 & 64.77 & .25 & 57.69 & 62.72 & 63.85 & 64.85 & 66.02 & 7 & \\
\hline 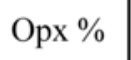 & & & & & & & & & & & 25.87 & 31.29 & 31.92 & 27.89 & 29.10 & 29.25 & 28.62 & & \\
\hline & & & & & & & & & & 9.06 & & 4 & 7.33 & 6.89 & 5.07 & 4.51 & 90 & & \\
\hline p1 & 1.91 & 1.02 & 5.00 & 1.59 & 2.20 & 2.1 & 2.1 & 2.12 & 2.13 & 2.76 & 2.39 & 2.22 & 3.06 & 2.50 & 1.98 & 1.39 & 1.38 & $1.3^{3}$ & \\
\hline 101 & 0.112 & 0.215 & 0.111 & 0.225 & 0.102 & 0.059 & 0.106 & 0.055 & 0.079 & 0.056 & 0.031 & 0.026 & & 0.067 & 0.045 & $\begin{array}{ll}5 & 0.034\end{array}$ & $\begin{array}{ll}4 & 0.088\end{array}$ & 8.023 & \\
\hline & 7.39 & 4.30 & 3.35 & 5.94 & 3.90 & 2.85 & 3.15 & 2.85 & 2.90 & 2.68 & 2.65 & 2.24 & 3.75 & 2.80 & 2.83 & 2.73 & 3.15 & 2.12 & \\
\hline
\end{tabular}

